University of Wollongong

Research Online

Faculty of Business - Papers (Archive)

Faculty of Business and Law

$1-1-2017$

\title{
Enabling a transformative service system by modeling quality dynamics
}

Shahriar Akter

University of Wollongong, sakter@uow.edu.au

Samuel Fosso Wamba

Toulouse Business School, samuel.fosso.wamba@neoma-bs.fr

John D'Ambra

University of New South Wales, j.dambra@unsw.edu.au

Follow this and additional works at: https://ro.uow.edu.au/buspapers

Part of the Business Commons

Research Online is the open access institutional repository for the University of Wollongong. For further information contact the UOW Library: research-pubs@uow.edu.au 


\title{
Enabling a transformative service system by modeling quality dynamics
}

\begin{abstract}
The increasing importance of service systems in the global economy prompts researchers to focus on quality to measure the critical interaction between human behavior, IT and society. Building on servicedominant logic and sociomaterialism, this study develops and validates a quality model and measures its overall impact on individual (value, satisfaction), organizational (i.e., continuance intentions) and social (e.g., quality of life) outcomes in the context of a transformative health service system in Bangladesh. The conceptual model is rooted in the traditional cognition (service quality) - affective (value, satisfaction)conation (continuance, quality of life) chain but explicitly identifies three primary dimensions and nine sub-dimensions of quality. The study advances theory and practice in service systems quality research by focusing on individual, economic and social outcomes.
\end{abstract}

Disciplines

Business

Publication Details

Akter, S., Fosso Wamba, S. \& D'Ambra, J. (2017). Enabling a transformative service system by modeling quality dynamics. International Journal of Production Economics, In Press 1-17.

This journal article is available at Research Online: https://ro.uow.edu.au/buspapers/1016 


\title{
Enabling Service systems by Modeling Quality Dynamics
}

\begin{abstract}
The increasing importance of service systems in the global economy prompts researchers to focus on quality to measure the critical interaction between human behavior, IT and society. Building on service-dominant logic and sociomaterialism, this study develops and validates a quality model and measures its overall impact on individual (value, satisfaction), organizational (i.e., continuance intentions) and social (e.g., quality of life) outcomes in the context of a transformative health service system in Bangladesh. The conceptual model is rooted in the traditional cognition (service quality) - affective (value, satisfaction)- conation (continuance, quality of life) chain but explicitly identifies three primary dimensions and nine sub-dimensions of quality. The study advances theory and practice in service systems quality research by focusing on individual, economic and social outcomes.
\end{abstract}

Keywords: Quality, Value, Satisfaction, Continuance, Service Systems. 


\section{INTRODUCTION}

The contribution of the services sector to all the advanced economies is growing with services now contributing more than $80 \%$ of their GDP (Dominguez-Péry et al., 2013; Maglio et al., 2015). This shift to service as a driver of economic growth is caused by the predominant presence of services industries (Rust and Huang, 2014). According to (Bloomberg, 2015), this global phenomenon of significant and sustained service growth in GDP is projected to continue unabated for both developed (e.g., 90\% for US) and developing countries (e.g., 50\% + for both India and China). Much of this growth is supported by Information and Communication Technology (ICT) driven service systems and relevant business models and processes (Huang and Rust, 2013). As such, service systems orientation can help organizations align its interests with the services economy by enhancing service quality and relevant service outcomes (Anderson and Ostrom, 2015; Maglio et al., 2015; Ostrom et al., 2015a). This orientation requires firms to understand the role of quality in order to perform better both at front stage and back stage (Akter and Ray, 2010; Sousa and Voss, 2006). Indeed, for better performance, service systems increasingly emphasize on quality to address the challenge: "how can the voice of the customer and voice of the process be matched for the best overall performance?"(IfM and IBM, 2007). Despite the importance of quality in service systems, there is a paucity of research that measures the antecedents to and consequence in this domain (Karpen et al., 2015). Indeed, service systems oriented thinking and quality dominant decision making are only beginning and a few preliminary guidelines for these links have been proposed. As organizations increasingly adopt service systems viewpoints, there is a need to embrace quality in evaluating individual, organizational and social outcomes of service systems (Maglio et al., 2009; Srinivasan and Kurey, 2014). While prior studies have focused on objective quality (or, hard dimensions), we empirically examine the role of quality in service systems capturing customers' perceptions (or, 
soft dimensions) because customers play a critical role in perceiving quality and their impact on value, satisfaction and quality of life (Dagger et al., 2007). According to Vargo and Lusch (2016,P.8), "firms should always involve customers (and in some cases other actors) in the design, definition, creation, completion (e.g., self-service), etc. of firm output (i.e., coproduction)". As such, the study develops and validates a quality model for a service system, which is based on service-dominant (S-D) logic (Vargo and Lusch, 2004, 2008) and sociomaterialism perspectives (Orlikowski, 2007). Using S-D logic, this study moves from traditional view of service quality that emphasizes dyadic one-to-one service encounters, to a more encompassing view of service quality within service systems. This view focuses on the holistic constellations within which quality dimensions becomes combined by service ecosystems (Vargo and Lusch, 2011). Using sociomaterialsim perspective, the study presents a balanced view by inextricably interlinking hierarchical quality model with social and material perspectives as they are inseparable in service systems research (Kim et al., 2012; Orlikowski, 2007).

Researchers in service systems consider quality as one of the most important determinants of businesses' long-term success (Rust and Huang, 2014; Srinivasan and Kurey, 2014). There is a growing need to reframe and refocus service quality in order to manage the critical outcomes of service systems (Alter, 2010). Limitations of the service systems approach at this point in time are the need to develop meaningful user-oriented quality assessment measures and their association with service outcomes. According to Bardhan et al. (2010a,p.6; Bardhan et al., 2010b) , "the deployment of IS and technology by firms increasingly determines their competitiveness in the service economy. In this milieu, there is a corresponding need to apply 
robust research findings in the appropriate managerial and organizational contexts on services innovation, quality, architecture, and design and delivery, as well as the customer satisfaction and business value that results". It is noteworthy that growing service systems including universities, banks or healthcare can transform our society by embracing quality dynamics. As such, there is a research call to encourage both researchers and practitioners to focus on quality in service systems research (Ostrom et al., 2015b; Rust and Huang, 2014; Srinivasan and Kurey, 2014).

'Service' is defined as the application of specialized competencies, through deeds, processes, and performances for the benefit of another entity or the entity itself (Vargo and Lusch, 2008), whereas 'service system' is defined as a value co-creating process using resources include people, technology, organization and shared information in order to satisfy customer needs better than competing alternatives (Edvardsson et al., 2011; IfM and IBM, 2007; Vargo et al., 2008). Synthesizing the findings of the extant literature, the study defines service system as a dynamic configuration of resources that co-creates value through interaction with its stakeholders (Spohrer et al., 2007). Viewing a system as a service or service systems orientation necessitate focusing on 'customers first' because changes in customers' needs lead to the desired changes in overall service system quality (SSQ), which in turn influences perceived value (VAL), satisfaction (SAT), continuance (CON) and quality of life (QOL). The research reported in this paper focuses on mHealth service system in developing countries. mHealth is an emerging health service system that is transformative in nature promoting wellness, prevention and selfmanagement rather than crisis intervention (Akter et al., 2013). 'mHealth' is defined as the application of mobile communications - such as mobile phones and PDAs - to deliver right time health services to customers (or, patients). In addition to the ubiquity of services, the importance 
of this service system in relation to patient well-being stems from patients' potential vulnerability. As a transformative service system, it centers on "creating uplifting changes and improvements in the well-being of both individuals and communities" (Ostrom et al., 2010, p.9). Although mHealth creates positive changes, there are growing concerns about the quality of such service systems, and their impact on individual, economic and social outcomes (Motamarri et al., 2014).

The research question of the study is: how do quality perceptions of a service system determine critical service outcomes? The answer to this research question clearly contributes to businesstechnology-community alignment of service systems research by framing quality on individual, economic and social outcomes. Specifically, this research makes three advances: first, using sociomaterialism perspective, we introduce entanglement view in developing a hierarchical quality model for a service system. Second, extending S-D logic in a transformative service system, we argue that the concept of holistic quality influences individual (i.e., VAL, SAT), organizational (i.e., CON) and social (i.e., QOL) outcomes of a service system. Third, we show the distinct roles of SSQ dimensions and sub-dimensions in adequately capturing quality dynamics in service systems research. The organization of this paper is as follows: Next section focuses on the literature review, conceptual model and hypotheses development. This is followed by method and findings. The last section focuses on theoretical and practical contributions and provides guidelines for future research. 


\section{BACKGROUND AND THEORY}

\subsection{Quality}

Quality is perhaps the most important and complex parameter of evaluating service performance (Golder et al., 2012). It is a key force leading to user satisfaction, IT success and the economic growth of a nation (Delone, 2003). A recent study shows that a company with better quality culture can save $\$ 350$ million in fixing mistakes than a competitor with poorly developed quality culture (Srinivasan and Kurey, 2014). Given this importance, quality is a fundamental concept with roots in many business disciplines including operations, marketing, information systems (IS), strategy and economics. To measure quality, SERVQUAL model is quite dominant in services literature and applied widely in industry such as, health care, public recreation centers, banking, etc., which sometimes indicates that scholars around the world are using SERVQUAL as a benchmark for their own industries (Parasuraman, 1990; Parasuraman et al., 1988). However, scholars (e.g., Brady and Cronin, 2001; Dagger et al., 2007) point to conceptual and empirical difficulties with the original SERVQUAL model and suggest a context-specific, hierarchical and multidimensional model. In a comprehensive review, Reeves and Bednar (1994) identified four dominant views: quality as excellence, quality as value, quality as conformance with specifications and quality as meeting expectations. According to Gronroos (2000), service quality is a complicated and indistinct concept and there is no single universal definition of quality in the literature. In addition, due to its 'elusive' nature (Gronroos, 2000; Reeves and Bednar, 1994), research in this sector has still remained 'unresolved' (Caruana et al., 2000). Indeed, service quality has remained a difficult concept to grasp and far from conclusive (Brady and Robertson, 2001). The extant research has undertaken either a production-oriented or customer-oriented view of quality (Gummesson, 1991). Whereas the production or 
manufacturing-based approach focused on objective or technical quality to measure standardized products (Caruana et al., 2000; Crosby, 1984; Gummesson, 1991), the customer-oriented approach focused on the perceptions of customers or quality in the eye of the customer (Andaleeb, 2008; Brady and Robertson, 2001; Crosby, 1984; Gummesson, 1991; Kasper et al., 1999; Oliver et al., 1997). Because of the complex nature of quality, the customer-oriented view has become the mainstream approach in defining quality in service research (Dagger et al., 2007; Schneider, 2004). According to Zeithaml (1988, p.5) "objective quality may not exist because all quality is perceived by someone". A recent interdisciplinary study on quality by Golder et al. (2012, p.9) also confirms this viewpoint: "The core feature of the quality evaluation process is the conversion of perceived attributes into an aggregated evaluation of quality, which is a summary judgment of the customer's experience of the firm's offering". These definitions reflect that quality of service should be viewed from the users' point of view to measure the performance level of an entity. This study defines service system quality (SSQ) as user's judgment of, or impression about, a service system's overall excellence or superiority which is consistent with the generic definitions in services' literature (Andaleeb, 2008; Brady and Cronin, 2001; Dagger et al., 2007; Gronroos, 2000; Grönroos, 1984; Parasuraman et al., 1988) . Overall, the study identifies that conceptualization and measurement of service quality in reference disciplines (e.g., marketing, information systems) is based on users' perceptions (Dagger et al., 2007; Parasuraman et al., 2005) in specific contexts (Jia et al., 2008; Xu et al., 2013).

\subsection{Service Quality in Operations}

Operations management scholars started focusing on quality in the 19th and early 20th century

(Sprague, 2007) including the quality circle and quality management movements, JIT/Lean, the cost of quality and design for manufacture and assembly (Sprague, 2007), measuring and control 
of service quality, strategic issues of quality in services (Machuca et al., 2007), six sigma, net promoter system process improvement $\mathrm{Wu}$ and $\mathrm{Wu}$ (2015). Recently, Yee et al. (2010) found that employee loyalty is considerably related to service quality, which in turn will have an impact on both customer satisfaction and customer loyalty, which ultimately will lead to firm profitability in high-contact service industries (Yee et al., 2010). Calabrese (2012) argued that perceived service quality and service productivity are two leading enablers of good performances in service companies (p. 800). Similarly, Hallikas et al. (2014) posited that in the service industry, firms have to focus both on cost efficiency and service quality in order to achieve a sustained competitive advantage. For example, high service quality may lead to high service value Hawkins et al. (2015), improved profit and turnover Dey et al. (2015), high service cocreation (Öhman et al., 2015), and therefore service quality can be viewed as "a judgment of performance excellence" (83) (Hawkins et al., 2015).

In order to recognize the critical role of service quality, researchers in marketing and information systems (e.g., Babakus and Boller, 1992; Jiang et al., 2000; Nelson et al., 2005; Parasuraman et al., 1985, 2005) have initially adopted SERVQUAL to measure service performance using five dimensions: reliability, responsiveness, assurance, empathy and tangibles. But technology driven service researchers faced huge challenges because of the reliability and validity of the generic SERVQUAL measures and lack of IT artifact (Jiang et al., 2000; Kettinger and Lee, 1994; Orlikowski and Iacono, 2001). Although such studies have been important in explaining service usage, they are relatively weak in capturing human-technology interactions and provide limited guidance for system designers (Nelson et al., 2005). Addressing the abovementioned concerns, Nelson et al. (2005) presented a model conceptualizing two basic dimensions of IS, that is, systems quality and information quality in order to establish an IT artifact in the IS quality 
literature. They identified nine dimensions of which five are for systems quality (i.e., systems reliability, systems efficiency, systems flexibility, systems privacy, systems integration) and four are for information quality (i.e., accuracy, completeness, currency and format). One of the limitations of this study was that the perspective was limited to data warehousing contexts thereby limiting the generalizability of the findings to other forms of technology. In a similar spirit, Wixom and Todd (2005) presented an integrated model focusing on system quality and information quality to explain the impact of IT on usage. While these studies significantly advanced quality research in IS usage, they did not provide comprehensive focus on the components and consequences of quality from service systems perspectives (Xu et al., 2013). Although Parasuraman et al. (2005), Fassnacht and Koese (2006) and Xu et al. (2013) shed further light on service quality in web services, however, their studies provided excessive focus on web centered quality, which leaves out service systems perspective. As such, the recent studies have made a renewed appeal for exploring quality dynamics in the service systems research (e.g., Golder et al., 2012; Lepmets et al., 2012; Maglio and Spohrer, 2013).Table 1 reviews the dimensions of service quality in a typical IS context, which frequently identifies system quality, interaction quality and information quality as the primary dimensions. 
Table 1: Constructs linked to Service Quality

\begin{tabular}{|c|c|c|}
\hline Seminal Studies on IT Service Quality & Constructs linked to service quality & Outcome constructs \\
\hline $\begin{array}{l}\text { (Kettinger and Lee, 1994, 1995, 1999, } \\
\text { 2005; Parasuraman et al., 1988), (Pitt et } \\
\text { al., 1997; Pitt et al., 1995) }\end{array}$ & $\begin{array}{l}\text { SERVQUAL dimensions (i.e., Reliability, responsiveness, assurance } \\
\text { and empathy) }\end{array}$ & User satisfaction, job performance \\
\hline (Jiang et al., 2000) & SERVQUAL dimensions & $\begin{array}{l}\text { Intention to use, use, user } \\
\text { satisfaction, net benefits }\end{array}$ \\
\hline (Delone, 2003) & System quality, information quality, service quality & $\begin{array}{l}\text { Information satisfaction, system } \\
\text { satisfaction, information*system } \\
\text { satisfaction }\end{array}$ \\
\hline (Nelson et al., 2005) & $\begin{array}{l}\text { System quality (reliability, flexibility, integration, accessibility\& } \\
\text { timeliness) and information quality (completeness, accuracy, format, } \\
\text { currency). }\end{array}$ & $\begin{array}{l}\text { Information satisfaction, system } \\
\text { satisfaction, usefulness, ease of use, } \\
\text { attitude, and intentions. }\end{array}$ \\
\hline (Wixom and Todd, 2005) & Similar dimensions proposed by Nelson et al. (Nelson et al., 2005) & Perceived value, loyalty intentions \\
\hline (Parasuraman et al., 2005) & $\begin{array}{l}\text { Core dimension: systems efficiency, systems availability, fulfilment } \\
\text { and privacy. Recovery dimensions: responsiveness, compensation } \\
\text { and contact }\end{array}$ & Overall customer satisfaction \\
\hline (Fassnacht and Koese, 2006) & $\begin{array}{l}\text { Environment quality (graphic quality and clarity of layout), delivery } \\
\text { quality (attractiveness of selection, information, ease of use, } \\
\text { technical quality) and outcome quality (reliability, functional benefit } \\
\text { and emotional benefits). }\end{array}$ & $\begin{array}{l}\text { Information satisfaction, system } \\
\text { satisfaction, service satisfaction, } \\
\text { usefulness, ease of use, enjoyment, } \\
\text { attitude, intention. }\end{array}$ \\
\hline (Xu et al., 2013) & $\begin{array}{l}\text { Information quality (completeness, accuracy, format and currency), } \\
\text { system quality (reliability, flexibility, accessibility and timeliness), } \\
\text { service quality (tangibles, responsiveness, empathy, service } \\
\text { reliability, assurance) }\end{array}$ & $\begin{array}{l}\text { Service satisfaction, perceived ease } \\
\text { of use, perceived usefulness. }\end{array}$ \\
\hline
\end{tabular}




\subsection{Conceptualization of quality in Service Systems using S-D Logic and Sociomaterialism}

The main concept in S-D logic focuses on service - the application of resources for the benefit of another party - is exchanged for service (Vargo and Lusch, 2004). S-D logic puts forward service centred relationship between suppliers and customers, which is predominantly customer oriented and supports the notion of value-in-use (Svensson and Grönroos, 2008; Vargo and Lusch, 2004). In general, the focal points of S-D logic highlight that: the basis of exchange is service, all social and economic actors are part of service as resource integrators, co-creation of value, and finally, value is always phenomenologically determined by a service beneficiary. These central premises of S-D logic are important to conceptualize quality in service systems.

The concept of service system is defined as "dynamic value co-creation configurations of resources (people, technology, organizations, and shared information)' (Maglio and Spohrer, 2008, p.18). A service system is a complex and dynamic network structures that consist of people, technologies, and other resources as an integrated whole influencing satisfaction and value creation (Edvardsson et al., 2011). It indeed highlights the centrality of continuous interactions, reticular relationships and value co-creation (Barile and Polese, 2010). In this context, studies also highlight the importance of viability in service systems by transforming socioeconomic relationships, which is a critical component of value co-creation in S-D logic (Barile and Polese, 2010; Vargo et al., 2008). The extant literature also argues that the viability of service systems is dependent on service excellence or quality of the overall service systems (Lusch et al., 2010 ; Vargo et al., 2008). In this regard, Lusch et al. (2007) argue that the idea of value co-creation in service systems is closely related to the quality-value-loyalty chain (Parasuraman and Grewal, 2000). In a similar vein, Karpen et al. (2015) focus on developing 
superior service systems quality to co-create value by integrating resources through S-D orientation. Ostrom et al. (2015a), in the context of transformative service systems, suggest linking service quality performance with individual, firm and social outcomes. However, the question arises as to which quality dimensions of a service system should get priority to transform service outcomes. In this regard, we argue that an entanglement view of sociomaterialism can help to answer this question. Based on this view, we identify that quality dimensions of a service system are so interwoven that it is difficult to measure their individual contribution in isolation (Orlikowski and Scott, 2008). This conceptualization also illuminates the fact that all the quality dimensions relevant to a service system are mutually supportive and constitutively entangled when the value of one resource is enhanced by the presence of other resources (Orlikowski, 2007). This viewpoint also states that quality dimensions of a system are entangled which could be leveraged through their synergistic ties (Kallinikos, 2007). Therefore, the study proposes an entanglement view of quality conceptualization which indicates that all the dimensions of quality act together in a synergistic fashion to influence service outcomes (e.g., satisfaction, value co-creation, continuance and quality of life). This paper intends to deepen and extend this stream of research by conceptualizing quality in service systems. Quality perceptions of such systems has the opportunity and power to affect social and economic outcomes for a transformative service system (Anderson et al., 2012). Although service systems are proposed to examine in terms of value co-creation, arguably even more important is modelling quality on well-being outcome (Anderson and Ostrom, 2015; Lucas Jr et al., 2013). 


\section{RESEARCH MODEL AND HYPOTHESES}

In order to develop a research model, this study began by investigating commonly cited dimensions that influence quality perceptions in service systems. The review identified three primary dimensions that reflect SSQ, that is, system quality, interaction quality and information quality. Throughout our review and theoretical exploration, SSQ was frequently identified as a higher-order and multidimensional construct, which indicated that several sub-dimensions would determine the initially identified primary dimensions. As such, we conducted qualitative study via two approaches: focus group discussions and (FGDs) and in-depth interviews (DIs) with users of the Grameen mHealth service system in Bangladesh under the auspices of the World Health Organization (WHO). Bangladesh is a world leader in the provision of mHealth service with a user base in excess of 50 million, which offers $24 / 7$ medical information, consultation, treatment, diagnosis, referral and counselling services by registered physicians via mobile phone.

The four FGDs $(n=32)$ focused on the service experience of users and the DIs $(n=20)$ obtained rich insights into the context mHealth service systems. The answers of both FGDs and DIs were recorded, synthesized and sorted into different themes using both manual thematic analysis and Nvivo (Dagger et al., 2007; Lincoln, 1985). The objective of this analysis was to identify the dimensions and sub-dimensions of mHealth service quality (D'Ambra and Rice, 2001). The analysis was conducted in several steps. Firstly, key responses were identified and highlighted in the transcript. Secondly, responses reflecting different dimensions of SSQ were categorized. Thirdly, recurring themes (or, sub-dimensions) were extracted under each dimension by two academic judges proficient in English and Bangla (Andaleeb, 2000, 2001, 2008). These academic judges were not part of the present study in order to ensure their neutral opinion on the development process (Moore and Benbasat, 1991). In this case, conflicting responses were 
discussed until agreement was reached and the overall inter-judge reliability was 0.86 exceeding the threshold level of 0.70 (Straub et al., 2004). Finally, each sub-dimension was doublechecked, refined and substantiated by revisiting the raw responses. The findings of the qualitative study identified service system quality as a multi-dimensional, hierarchical and context specific concept. Users confirmed different service-level attributes (e.g., "I can access mHealth systems whenever I want" or, "The physician shows sincere interest to solve my problems," or, "It is worthwhile having information from this service system") under three primary dimensions, which are discussed below.

\subsection{Systems Quality}

Systems quality in mHealth service system reflects users' perceptions regarding the technical level of communication (Delone, 2003; DeLone and McLean, 1992; Petter and McLean, 2009). Four core sub-dimensions emerged as users' perceptions of systems quality in mHealth service systems: system reliability; system efficiency, system flexibility and system privacy. The first sub-dimension, system reliability, indicates the degree to which the mHealth system is dependable over time (Delone, 2003; Nelson et al., 2005; Parasuraman et al., 2005) measuring service promise as indicated by the following comments "It performs smoothly" and "It is dependable". The second sub-dimension, systems efficiency, defines the degree to which the mHealth service system is easy to use (Parasuraman et al., 2005). It measures use efficiency of the service system, as reflected by the following comments: "this service system is simple to use" or "this service system is easy to use". The third sub-dimension, systems flexibility, indicates the degree to which a system can be adapted to a variety of user needs and changing conditions (Delone, 2003; Nelson et al., 2005; Parasuraman et al., 2005). In fact, it reflects the flexibility of the system as reflected by the comment "It can flexibly adjust to meet my variety of 
needs." Systems privacy, the final sub-dimension, relates to the extent to which the mHealth system protects the privacy of patients' health information. (Parasuraman et al., 2005; Varshney, 2005). In mHealth, 'privacy' has always been cited as an important parameter to gain reliance on the service systems, as reflected by the comments "It protects my personal information" and "It offers me a meaningful guarantee of my privacy". Therefore, the study proposes four subdimensions as the important aspects of mHealth system quality.

\subsection{Interaction Quality}

Interaction quality indicates the quality of interpersonal interaction and the interplay between mHealth service system and a user (Dagger et al., 2007). It is defined as a period of time during which a consumer directly interacts with a service (Bitner, 1990). The emerging subdimensions of this construct are: knowledge and competence of the provider, promptness in providing solutions and individual attention. Three core subdimensions underpinned customers' perceptions of interaction quality: responsiveness, assurance and empathy. The first subdimension, responsiveness, refers to the willingness of the service provider to help users and to deliver prompt service (Parasuraman et al., 1988; Sousa and Voss, 2006). Participants in the qualitative interview referred to this factor as willingness and promptness of the provider to deliver the mHealth service, as indicated by the comment, "Physicians show a sincere interest to solve my problems." The second sub-dimension, assurance, measures the perceived safety of the mHealth system (Parasuraman et al., 1988; Sousa and Voss, 2006). Safety is critical in generating patient trust and confidence: "I feel safe while consulting with physicians" and "Physicians' behavior stimulates my confidence to deal with this healthcare system". The third sub-dimension of empathy measures the perceived caring and individualized attention of the provider to the patients (Parasuraman et al., 1988; Sousa and Voss, 2006). Comments such as 
"Physicians give me individual care" or "Physicians understand my specific needs" are evidence of the importance of care in the interaction quality. Therefore, the study puts forward three subdimensions as the salient indicators of interaction quality in the context of mHealth service systems.

\subsection{Information Quality}

This study proposes information quality as a critical dimension of mHealth service system, which refers to what a user (or patient) receives as a result of his or her interactions with an mHealth provider. The extant literature highlights the importance of perceived information quality in service systems in terms of several service benefits, which may have varying importance to the user (Nelson et al., 2005). The direct relationship between information quality (or, service benefits) and service quality is also cited in some health care studies (Andaleeb, 2001; Xu et al., 2013). The findings of the qualitative study supported two key sub-dimensions, that is, utilitarian and hedonic information quality (Fassnacht and Koese, 2006). The first subdimension, utilitarian information, relates to how well the mHealth service system fits it actual purpose. During the exploratory study, it was frequently discussed as an important parameter, as indicated by the comments, "It serves its purpose very well" or "It is very useful". Previous studies in IS have demonstrated the critical role that utilitarian information (i.e. usefulness) plays in promoting a positive response by users to information (Bhattacherjee, 2001; Davis, 1989; Limayem et al., 2007). The second sub-dimension of hedonic information relates to the extent to which the mHealth service system generates positive feelings as demonstrated by the following comments: "I feel hopeful having service from this system"; "I believe my future health will improve having this service". This hedonic benefit has received much attention in recent years to stimulate users' beliefs regarding service quality perception (Sweeney and Soutar, 2001). Thus 
we propose information quality as an important aspect of mHealth service system, which captures utilitarian and hedonic characteristics.

\subsection{Quality in mHealth service systems: A hierarchical model}

Based on the qualitative findings and supporting literature, a conceptual model of quality is proposed in Figure 1 to measure the dimensions and sub-dimensions of mHealth service system. We specify quality as a hierarchical, multidimensional model which is comprised of three primary dimensions (i.e., system quality, interaction quality and information quality) and nine sub-dimensions (i.e., system reliability, system efficiency, system flexibility, system privacy, responsiveness, assurance, empathy, utilitarian and hedonic information). Based on the decision criteria of seminal studies in hierarchical model (Becker et al., 2012a; Jarvis et al., 2003; Petter et al., 2007; Polites et al., 2011), we argue that the quality in mHealth service system is a reflectiveformative model, in which the first-order constructs are reflective and the second-order and thirdorder constructs are formative (see Figure 1). In the first-order model, measures are manifestations of constructs, that is, all the measures under a construct share a common theme (Jarvis et al., 2003; Petter et al., 2007; Polites et al., 2011). In our study, for example, systems privacy was manifested by three measures: "It protects my personal information", "It does not share information with others" and "It offers me a meaningful guarantee of my privacy". Aligned with the established decision criteria on model specification, these three measures are interchangeable and share one theme. The extant literature on quality (Dagger et al., 2007) and measurement model specifications (Bagozzi, 2011; Edwards, 2001; Jarvis et al., 2003; Polites et al., 2011; Wetzels et al., 2009) supports this view of hierarchical modeling, which is also consistent with our theoretical proposition of entanglement view. 




Figure 2: Quality dimensions in mHealth service systems

\subsection{Effects of quality in mHealth service systems}

This study identifies mHealth as a transformative service system as it redefines health care delivery in a new market space by forming a strategic alignment among business, technology and well-being (Lucas $\mathrm{Jr}$ et al., 2013). mHealth service system dramatically changes healthcare delivery by serving a vast number of unserved customers and gaining competitive advantages by doing things differently (Akter and Ray, 2010). Figure 2 encapsulates the outcomes of quality in mHealth service systems. Epistemologically, the research model embraces an explaining and predicting paradigm (Gregor, 2006) and a proxy view of an IT artifact (Orlikowski and Iacono, 2001). Ontologically, the model extends knowledge by modeling the impact of SSQ on 
individual (value, satisfaction), economic (continuance) and social (quality of life) outcomes. Drawing on S-D logic as discussed earlier, the conceptual model embraces an interdisciplinary approach to tackle the service systems challenges and opportunities (Huang and Rust, 2013; Maglio et al., 2015). Figure 2 provides an overview of the relationships of a cognitive (SSQ) affective (VAL, SAT)-conative (i.e., CON \& QOL) framework (Bhattacherjee, 2001; Brady and Robertson, 2001; Chiou and Droge, 2006; Cronin and Taylor, 1992; Dagger et al., 2007; Oliver, 1999; Oliver et al., 1997; Patterson and Spreng, 1997; Taylor and Baker, 1994; Woodside et al., 1989). The model goes some way in simplifying the quality dominant decision-making process for service systems research by linking user beliefs, affect and intention within the user attitude structure beginning with cognitive beliefs followed by affective responses ending with conative effects.

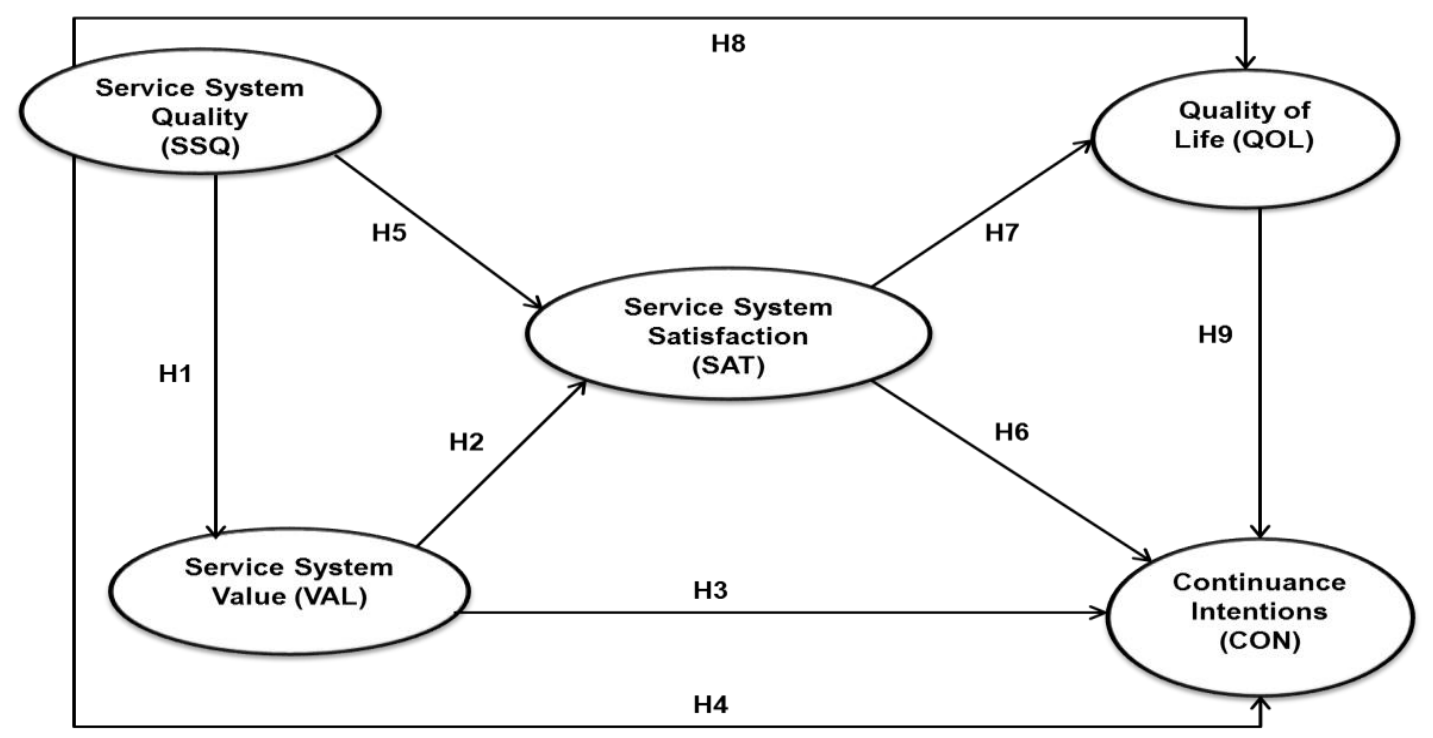

Figure 2: Effects of quality in a transformative service system

\subsubsection{The Effects of SSQ on VAL, SAT \& CON}

In assessing service systems, perceived VAL plays a critical role in measuring benefits and costs (Alter, 2010). According to (Vargo et al., 2008, p.146) "value and value creation are at the heart 
of service and are critical to understanding the dynamics of service systems and to furthering service science". VAL refers to the consumer's evaluation of the utility of perceived benefits and perceived sacrifices (Zeithaml, 1988). In other words, it refers to users' perception regarding what they receive as benefits and what they give up as sacrifices in order to achieve a service (Choi et al., 2004). The study takes the view that value is not realized until the service system is used - that is, perceived value-in-use (Lusch and Vargo, 2006; Ng et al., 2011; Payne et al., 2008). In the context of healthcare, Porter and Teisberg (2004, p.5) state "Payers, employers and providers pay insufficient attention to achieving better outcomes and improving value over time, which are what really matter". Superior service value delivers competitive advantage, profitability and user satisfaction for service systems (Parasuraman et al., 2005). Service providers are motivated by increasing service and/or reducing costs (Sheth et al., 1991). The extant literature reports that perceived VAL of services will be directly influenced by perceived SSQ. The relationship between SSQ and VAL is evident in healthcare (Cronin et al., 1997) and other services (Athanassopoulos, 2000; Fornell et al., 1996; Wakefield and Barnes, 1997). Thus, the study hypothesizes that:

H1: Perceived SSQ positively influences perceived VAL of a service system.

One of the fundamental building blocks of service systems is to ensure VAL and SAT (Maglio et al., 2009) . In mobile technology based service systems, VAL receives increased attention as firms use direct-interactive channel to co-create value with customers (Kalakota and Robinson, 2001). As noted by Chatterjee et al. (2009), the demand side of mobile service system (i.e., mHealth) is driven by VAL, and hence there is a need to build an understanding of the elements and special features from users' perspectives. For mHealth consumers, the key value 
propositions are co-creation of choice, or new freedoms, for patients (Akter and Ray, 2010). In other words, the key advantages of mHealth include flexibility, convenience and ubiquity. According to Fornell et al. (1996, p.9) "The first determinant of overall customer satisfaction is perceived quality. The second determinant of overall customer satisfaction is perceived value". Thus, we posit that:

H2: Perceived VAL positively influences perceived SAT of a service system.

The extant literature (e.g., Akter et al., 2013) indicates that mHealth continuance decisions by patients are determined by the value of a service channel in comparison to existing alternatives. The majority of studies indicate that SSQ has an indirect impact on behavioral intentions through VAL and SAT (Lai et al., 2009; Parasuraman et al., 2005; Patterson and Spreng, 1997; Ruiz et al., 2008), though others argue for a direct impact (Boulding et al., 1993; Taylor and Baker, 1994; Zeithaml et al., 1996). Therefore, we are interested to explore the impact of VAL on CON through the following hypothesis:

H3: Perceived VAL positively influences perceived CON of a service system.

It is also argued that CON is the result of a customer's perception of SSQ. Whereas 'intention to use' is related to the initial adoption stage and considered a first step towards overall success a service system, 'continuance intentions' focus on how to promote continued system use or how to reduce discontinuance (Limayem et al., 2007). Prior literature has linked quality with satisfaction and behavioral intentions in the health care context (Dagger et al. 2007); however, there are few studies which have modeled the direct impact of SSQ on CON. Therefore, this study addresses this gap by putting forward the hypothesis: 
H4: Perceived SSQ positively influences perceived CON of a service system.

\subsubsection{The Effects of SSQ on SAT, CON and $Q O L$}

Service quality is fundamental to successful service systems (Alter, 2010). Systems scholars have suggested that quality-based approaches to measuring satisfaction are a significant indicator of performance (Nelson et al., 2005; Wixom and Todd, 2005). According to Delone (2003, p.17) "[i]t is essential that IS researchers distinguish between the management control variables and the desired results in terms of quality, use satisfaction, and impacts". Similarly, the health care literature also suggests that satisfaction should be modeled individually and linked with overall service quality in order to measure service outcomes (Dagger et al., 2007). In traditional health care literature, service quality plays an increasingly important role as a tool to ensure patient satisfaction, identify target groups, define measures of performance and develop performance information systems. In health care, SAT is a significant indicator measuring the effects of quality or overall service performance and can lead to improvements in patient retention and profitability (Aharony and Strasser, 1993; Säilä et al., 2008). SAT is a significant and integral component of health service system's strategic processes (Andaleeb, 2001; Choi et al., 2004) and should receive equal importance as SSQ in order to design and manage the health care systems effectively. The extant literature identifies SAT as an affective response to the cognitive service quality approach. This differential indicates a causal relationship between SSQ and SAT with SSQ as an antecedent to SAT, such a relationship is supported by numerous studies in health care settings (e.g., Andaleeb, 2001; Choi et al., 2004; Dagger et al., 2007). According to Golder et al. (2012, p.12) "Positive quality disconfirmation increases satisfaction; negative quality disconfirmation decreases satisfaction". Thus, to confirm the relationship between SSQ and SAT 
in service systems, we posit that:

H5: Perceived SSQ positively influences perceived SAT of a service system.

With regard to the direct impact of SAT on CON, DeLone and McLean (2003) found that an increased satisfaction leads to future intentions to use. They confirmed an association between service satisfaction and future use intentions through their meta-analysis. Rai et al. (2002), in their study to assess the validity of DeLone and McLean's (1992) and Seddon's (1997) IS success models, found that satisfaction of service systems impacts on IS use and a higher level of satisfaction creates greater user dependence on the system. Continuance refers to post-adoption, which actually refers to a suite of behaviors that follow initial acceptance, including routinization, infusion, adaptation, assimilation (Bhattacherjee, 2001; Karahanna et al., 1999). Thus, the study presents the hypothesis to measure the impact of SAT on CON:

H6: Perceived SAT positively influences perceived CON of a service system.

There is an intricate relationship between SSQ, SAT and QOL perceptions (Dagger and Sweeney, 2006). According to Lusch et al. (2007,p.12), "customer is a primary integrator of resources in the creation of value through service experiences that are interwoven with life experiences to enhance quality of life". QOL is generally viewed as the well-being and happiness of individuals (Ferrans and Powers, 1992; Sirgy et al., 2006; Yuan, 2001). It is a subjective concept (Dagger and Sweeney, 2006) which is often used interchangeably with the well-being of life (Endres, 1999; Yuan, 2001). Broadly, QOL can be conceptualized as an overall measure or as a measure based on experiences in a variety of domains, such as health care, work, family and 
leisure (Lee et al., 2002). Thus, from the holistic viewpoint, QOL refers to the subjective evaluation of one's current life circumstances (Dagger and Sweeney, 2006; Inglehart and Rabier, 1986). However, in the health care context, QOL is viewed as a subjective, individual, experiential construct which measures overall well-being in a particular health care domain (Dagger and Sweeney, 2006). In reference disciplines (e.g., economic psychology, marketing), the relationship between SSQ, SAT and QOL has been explored to evaluate the performance of a service (Poiesz and von Grumbkow, 1988; Sirgy and Cornwell, 2001). In information systems, performance is generally measured in terms of its effectiveness in achieving goals (Gefen et al., 2003) or satisfaction of using for a particular task (Bhattacherjee and Premkumar, 2004). The typical outcome variables in IS measures users' feelings or attitudes at the time they use the system, rather than the impact of the system on their overall quality of life (Choi et al., 2007). Although the impact of service systems on QOL has been frequently discussed in the service science research, scholars in service systems have paid little attention to social outcomes. This gap has recently received greater attention in systems research as scholars believe that IT should focus on transforming the QOL of its users (Lucas Jr et al., 2013). Thus, the study hypothesizes that:

H7: Perceived SAT of a service system positively influences QOL perception.

H8: Perceived SSQ of a service system positively influences QOL perception.

Similarly, service systems researchers have put little effort into measuring the connection between social and economic outcome of a health service system, which is reflected in Rosenbaum's (2008, p.179) statement, “[y]et empirical research exploring the health benefits of commercial support is lacking and relatively absent in the services literature". It is noteworthy that QOL is different from the traditional financial or growth-related outcome construct as it is 
focused on measuring the customer well-being or societal welfare of a service provision (Dagger and Sweeney, 2006). In the mHealth service system context, QOL assessment is particularly important as this new health care paradigm is frequently referred to as a transformative service system due to its strong positive impact on patients' quality of health life in developing countries (Anderson and Ostrom, 2015; Anderson et al., 2012). As such, it is important to understand how QOL evaluations influence economic outcome (i.e., CON). Despite a natural relationship between QOL and CON, few studies have developed metrics to assess this relationship. Thus, we propose:

H9: Perceived QOL positively influences continuance intentions of a service system.

\subsubsection{Mediating Effects of satisfaction and value}

Satisfaction and value are major drivers of positive QOL perception and continuance intentions, and, therefore, achieving high satisfaction and value are key goals of service systems around the world (Maglio et al., 2015). This study identifies SAT and VAL as mediators because, first, SSQ (predictor) influences SAT and VAL (mediators); second, SAT influences QOL and CON and, VAL influences SAT and CON. Finally, SSQ influences the criterion variables in the absence of the mediators' (i.e., SAT \& VAL) influence (Baron and Kenny, 1986). In addition, SAT and VAL as mediators play the role of an 'affective' attitude between 'cognitive beliefs' (i.e., SSQ) and 'conative' constructs (i.e., CON and QOL), which draw much attention in information systems (Bhattacherjee, 2001), psychology (Ajzen and Fishbein, 1980) and marketing literature (Bansal et al., 2005; Dagger and Sweeney, 2006; Lai et al., 2009). In service systems, VAL is widely acknowledged to play a vital role between SSQ-SAT and SSQ-CON in order to ensure its scalability and sustainability (Maglio and Spohrer, 2013). Thus, we put forward the hypotheses: 
H10.1: VAL mediates the relationship between SSQ and SAT.

H10.2: VAL mediates the relationship between SSQ and CON.

Similarly, studies have discussed an indirect relationship between service quality and social outcomes through satisfaction (Dagger and Sweeney, 2006). According to Choi et al. (2007,p.599), "IS research has examined the individual, organizational, and social impact of information systems, but again without directly addressing the impact of IS on QOL" (Choi et al. 2007). As such, it is important to understand how SAT mediates the relationship between SSQ QOL (i.e., social outcome) and SSQ-CON (i.e., economic outcome). Despite a natural relationship between SSQ-SAT-QOL-CON, few studies have developed metrics to assess this relationship. Thus, we hypothesize that:

H11.1: SAT mediates the relationship between SSQ and QOL.

H11.2: SAT mediates the relationship between SSQ and CON.

\section{METHODOLOGY}

\subsection{Instrument Development}

Multi-item scales have been adopted from the literature. Scales were calibrated to the context of mHealth service systems where required. Table 2 provides the constructs and their attributes as well as sources for the scales. 7 point Likert scales were used to measure the constructs except satisfaction. A bi-polar semantic differential scale (i.e. very dissatisfied - very satisfied was used to measure satisfaction. The survey was originally composed in English and then translated into Bengali, the local language. The Bengali version was then translated back into English. A 
panel of experts fluent in English and Bengali verified that both version reflected the same content (Andaleeb, 2001). A pretest of the Bengali survey was done with a convenience sample of 30 confirming that the question wording, format, sequence, length, range of scales and instructions were appropriate. Based on the pretest results, some revisions were made.

Table 2: Operationalization of constructs

\begin{tabular}{|c|c|c|c|}
\hline Constructs & Sub-constructs & Definitions & Studies \\
\hline $\begin{array}{l}\text { Systems } \\
\text { Quality }\end{array}$ & $\begin{array}{l}\text { Systems } \\
\text { Reliability } \\
\text { Systems } \\
\text { Flexibility } \\
\text { Systems } \\
\text { Efficiency } \\
\text { Systems } \\
\text { Privacy }\end{array}$ & $\begin{array}{l}\text { The degree to which mHealth service system is dependable } \\
\text { over time. } \\
\text { The degree to which mHealth is adaptable to meet variety } \\
\text { of needs. } \\
\text { The degree to which mHealth service system is easy to use } \\
\text { and adapt to a variety needs and changing conditions. } \\
\text { The degree to which mHealth service system is safe and } \\
\text { protects user information. }\end{array}$ & $\begin{array}{l}\text { (Nelson et al., 2005) } \\
\text { (Nelson et al., 2005) } \\
\text { (Parasuraman et al., } \\
\text { 2005) } \\
\text { (Parasuraman et al., } \\
\text { 2005) }\end{array}$ \\
\hline $\begin{array}{l}\text { Interaction } \\
\text { Quality }\end{array}$ & $\begin{array}{l}\text { Responsiveness } \\
\text { Assurance } \\
\text { Empathy }\end{array}$ & $\begin{array}{l}\text { It refers to the willingness of physicians to help patients } \\
\text { and provide prompt service over mHealth service system. } \\
\text { It measures knowledge of the service provider to inspire } \\
\text { trust and confidence of users. } \\
\text { It measures caring and individualized attention of the } \\
\text { provider to its users. }\end{array}$ & $\begin{array}{l}\text { (Parasuraman et al., } \\
1988)\end{array}$ \\
\hline $\begin{array}{l}\text { Information } \\
\text { Quality }\end{array}$ & $\begin{array}{l}\text { Utilitarian } \\
\text { Hedonic }\end{array}$ & $\begin{array}{l}\text { The extent to which the mHealth information serves its } \\
\text { actual purpose. } \\
\text { The extent to which using the mHealth information } \\
\text { arouses positive feelings. }\end{array}$ & $\begin{array}{l}\text { (Fassnacht and } \\
\text { Koese, 2006) }\end{array}$ \\
\hline $\begin{array}{l}\text { Outcome } \\
\text { Constructs }\end{array}$ & $\begin{array}{l}\text { Value } \\
\text { Satisfaction } \\
\text { Continuance } \\
\text { Quality of life }\end{array}$ & $\begin{array}{l}\text { Users' trade-off between benefits and costs. } \\
\text { Users' affect with (or, feelings about) prior mHealth } \\
\text { service system use. } \\
\text { Users' intentions to continue using mHealth service } \\
\text { system. } \\
\text { QOL is defined as a sense of overall well-being in health. }\end{array}$ & $\begin{array}{l}\text { (Parasuraman et al., } \\
\text { 2005) } \\
\text { (Spreng et al., 1996) } \\
\text { (Bhattacherjee, } \\
\text { 2001); (Choi et al., } \\
\text { 2007) }\end{array}$ \\
\hline
\end{tabular}




\subsection{Sampling}

Area wise cluster sampling was used from two urban regional areas and three rural regional areas. A socio-economic criterion was used to provide diversity in the sample. From each region, thanas (a local community) were selected randomly; thanas were then dissected into streets/villages and finally residential homes were selected from each street/village. Simple random sampling was used to ensure that each sample/element had an equal chance of being selected. The unit of measurement was patient (or, customer) who had experience with the mHealth service in the past 12 months. All potential respondents were provided with the ethics approval documentation for the study from the university conducting the study. Contact details for confirmation were provided as part of the documentation as well as confidentiality arrangements.

\begin{tabular}{|c|c|c|c|c|c|}
\hline \multicolumn{6}{|c|}{ Table 3: Demographic profile of respondents } \\
\hline Items & Categories & $\%$ & Items & Categories & $\%$ \\
\hline Gender & $\begin{array}{ll}\text { 1. } & \text { Male } \\
\text { 2. } & \text { Female }\end{array}$ & $\begin{array}{l}59 \\
41\end{array}$ & \multirow[t]{2}{*}{ Age } & \multirow{2}{*}{$\begin{array}{ll}\text { 4. } & 18-25 \\
5 . & 26-33 \\
6 . & 34-41 \\
7 . & 42-49 \\
8 . & 50+\end{array}$} & \multirow{2}{*}{$\begin{array}{l}25 \\
32 \\
21 \\
17 \\
5\end{array}$} \\
\hline Location & $\begin{array}{ll}\text { 1. } & \text { Urban } \\
\text { 2. } & \text { Rural }\end{array}$ & $\begin{array}{l}42 \\
58\end{array}$ & & & \\
\hline $\begin{array}{l}\text { Income } \\
\text { (per month in } \\
\text { US \$) }\end{array}$ & $\begin{array}{l}<\$ 70 \\
\$ 71-\$ 141 \\
\$ 142-\$ 212 \\
\$ 212+\end{array}$ & $\begin{array}{l}47 \\
22 \\
10 \\
21\end{array}$ & Occupation & $\begin{array}{ll}\text { 1. } & \text { Working full time } \\
\text { 2. } & \text { Working part time } \\
\text { 3. } & \text { Stay-at-home spouse } \\
\text { 4. } & \text { Others }\end{array}$ & $\begin{array}{l}38 \\
34 \\
16 \\
12\end{array}$ \\
\hline
\end{tabular}

A total of 507 respondents were approached, of which $325(64 \%)$ surveys were ultimately completed. Of the total number of completed surveys, seven were considered problematic and excluded, because of excessive missing data, don't know answers, or N/A answers, and response biases. Finally, 311 surveys were analyzed. Although response rate was satisfactory, we 
investigated the possibility of non-response bias by comparing the profiles of the survey respondents and those on the sample frame in terms of demographic variables, and no nonresponse bias was found through the chi-square tests (Kim et al., 2012). We also did not find any significant response bias as we compared the early (20 percent) and late ( 20 percent) response groups on the survey items using the paired t-tests.

The demographic profile of the respondents represents a diverse cross section of the population. The demographic data of the respondents is as follows: age ranged from 18 to 62,59 percent male, 58 percent lived in rural areas, 47 percent had income less than US $\$ 70$ per month, employment included a wide range of professions (students, professionals, self-employed, academics, farmers, stay-at-home spouses, day laborers, retirees), education levels varied from primary to doctoral degrees (see table 3).

\subsection{Data Analysis}

Service quality in this study serves as a higher-order construct which contains three first-order dimensions and eight second-order dimensions. The study applies repeated indicator approach to estimate all the constructs simultaneously instead of separate estimate of lower-order and higherorder dimensions (Becker et al., 2012a). The study specifies the mode of measurement as reflective-formative as the first-order dimensions are reflective (Mode A) and higher-order dimensions are formative (Mode B) (Chin, 2010; Ringle et al., 2012). The study estimates the model using PLS path modeling because it can ensure more theoretical parsimony and less model complexity (Chin, 2010; Edwards, 2001; Law et al., 1998; MacKenzie et al., 2005; Wetzels et al., 2009). Specifically, the study applies PLS because, first, this approach is consistent with the objective of the study, which aims to develop and test a theoretical model 
through explaining and prediction (Chin, 2010; Hair et al., 2011). Second, PLS can effectively handle various constraints with regard to hierarchical modeling in terms of distributional properties (multivariate normality), measurement level, sample size, model complexity, identification, and factor indeterminacy (Chin, 1998b, 2010; Fornell and Bookstein, 1982; Hair et al., 2011; Hulland et al., 2010). PLS is particularly suitable for relatively complex hierarchical models and when the phenomena of interest are new or versatile.

SmartPLS 3.0 (Ringle et al., 2015) was used to estimate the high-order, reflective-formative model with the repeated use of manifest variables. In this case, the study applied a path weighting scheme for the inside approximation (Chin, 1998a; Tenenhaus et al., 2005; Wetzels et al., 2009). The study applied nonparametric bootstrapping (Chin, 1998a; Efron and Tibshirani, 1993; Tenenhaus et al., 2005) with 5000 replications to obtain the standard errors of the estimates (Hair Jr et al., 2013). A recent study conducted by Becker et al. (2012a) found that the repeated indicator approach for reflective-formative models with path weighting scheme produces the best parameters. As per the guidelines of hierarchical modeling (Becker et al., 2010; Chin, 2010), an equal number of indicators were repeatedly used to estimate the scores of first-order constructs (i.e., systems reliability, systems efficiency, systems flexibility, systems privacy, responsiveness, assurance, empathy, utilitarian, hedonic) and second-order constructs (systems quality, service quality and information quality). As such, the study created the higherorder SSQ construct that represents all the indicators of the underlying first-order latent variables. 


\section{FINDINGS}

\subsection{Measurement Model}

Confirmatory factor analysis (CFA) was used to verify the convergent and discriminant validity of the first-order measurement model (Table 4). The 13 constructs that make up this first-order model are: systems reliability, systems efficiency, systems flexibility, systems privacy, responsiveness, assurance, empathy, utilitarian and hedonic information, satisfaction, value continuance intentions and QOL. Initially, the study calculated all the item loadings which exceeded the cut-off values of 0.7 and were significant at $p<0.001$. The higher average of item loadings ( $>0.80$ ) and a narrower range of difference provide strong evidence that respective items have greater convergence in measuring the underlying construct (Chin, 2010). The study also calculated average variance extracted (AVE) and composite reliability (CR) (Chin, 1998a; Fornell and Larcker, 1981) to confirm reliability of all the measurement scales. AVE measures the amount of variance that a construct captures from its indicators relative to measurement error, whereas $C R$ is a measure of internal consistency (Chin, 2010). Basically, these two tests indicate the extent of association between a construct and its indicators. CR and AVE of all scales are either equal to or exceed respectively 0.80 and 0.50 cut-off values (Fornell and Larcker, 1981). Here, the lowest AVE is 0.707 for utilitarian information and the lowest CR is 0.881 for systems availability; all these values exceed the recommended thresholds. Thus, the study confirmed that all the item loadings, CRs and AVEs exceed their respective cut-off values and ensure adequate reliability and convergent validity (Chin, 1998a; Fornell and Larcker, 1981). 
Table 4: Assessment of First-Order, Reflective Model

\begin{tabular}{|c|c|c|c|c|}
\hline Constructs & Items & Loadings & CR & $\overline{\text { AVE }}$ \\
\hline $\begin{array}{l}\text { System } \\
\text { Reliability }\end{array}$ & $\begin{array}{l}\text { mHealth service system works smoothly. } \\
\text { mHealth service system performs reliably. } \\
\text { mHealth service system is dependable. }\end{array}$ & $\begin{array}{l}0.893 \\
0.924 \\
0.938\end{array}$ & 0.941 & 0.843 \\
\hline $\begin{array}{l}\text { System } \\
\text { Efficiency }\end{array}$ & $\begin{array}{l}\text { This service system is simple to use. } \\
\text { It is easy to use. } \\
\text { It is well organized. }\end{array}$ & $\begin{array}{l}0.865 \\
0.818 \\
0.812\end{array}$ & 0.865 & 0.681 \\
\hline $\begin{array}{l}\text { System } \\
\text { Flexibility }\end{array}$ & $\begin{array}{l}\text { It can be adapted to meet a variety of needs. } \\
\text { It can flexibly adjust to new demands and conditions. } \\
\text { It is versatile in addressing needs as they arise. }\end{array}$ & $\begin{array}{l}0.927 \\
0.960 \\
0.914 \\
\end{array}$ & 0.953 & 0.871 \\
\hline $\begin{array}{l}\text { System } \\
\text { Privacy }\end{array}$ & $\begin{array}{l}\text { It protects my personal information. } \\
\text { It does not share information with others. } \\
\text { It offers me a meaningful guarantee. }\end{array}$ & $\begin{array}{l}0.925 \\
0.962 \\
0.944\end{array}$ & 0.961 & 0.891 \\
\hline Responsiveness & $\begin{array}{l}\text { Physicians are always willing to help me. } \\
\text { They show interest to solve my problems. } \\
\text { They provide service right at the first time. }\end{array}$ & $\begin{array}{l}0.906 \\
0.911 \\
0.907\end{array}$ & 0.933 & 0.824 \\
\hline Assurance & $\begin{array}{l}\text { Their behavior instills confidence in me. } \\
\text { I feel safe while consulting with them. } \\
\text { They are competent in providing service. }\end{array}$ & $\begin{array}{l}0.841 \\
0.892 \\
0.894\end{array}$ & 0.908 & 0.768 \\
\hline Empathy & $\begin{array}{l}\text { Physicians give me personal attention. } \\
\text { Physicians give me individual care. } \\
\text { Physicians understand my specific needs. }\end{array}$ & $\begin{array}{l}0.931 \\
0.940 \\
0.874\end{array}$ & 0.939 & 0.838 \\
\hline $\begin{array}{l}\text { Utilitarian } \\
\text { Information }\end{array}$ & $\begin{array}{l}\text { Information from mHealth service system serves its } \\
\text { purpose very well. } \\
\text { Information is provided according to my needs. } \\
\text { Information is very useful to me. }\end{array}$ & $\begin{array}{l}0.814 \\
0.840 \\
0.834\end{array}$ & 0.868 & 0.688 \\
\hline $\begin{array}{l}\text { Hedonic } \\
\text { Information }\end{array}$ & $\begin{array}{l}\text { I feel hopeful as a result of having information. } \\
\text { I feel encouraged having this information. } \\
\text { I believe my future health will improve having this } \\
\text { information service. }\end{array}$ & $\begin{array}{l}0.961 \\
0.952 \\
0.945\end{array}$ & 0.967 & 0.907 \\
\hline $\begin{array}{l}\text { Perceived } \\
\text { Value }\end{array}$ & $\begin{array}{l}\text { The amount of money I paid for this service is appropriate. } \\
\text { The value I receive for my money is worthwhile. } \\
\text { Overall, mHealth service system offers value to me. }\end{array}$ & $\begin{array}{l}0.917 \\
0.908 \\
0.939\end{array}$ & 0.944 & 0.849 \\
\hline $\begin{array}{l}\text { Service } \\
\text { satisfaction }\end{array}$ & $\begin{array}{l}\text { I am satisfied with my use of mHealth service system. } \\
\text { I am contented with my use of mHealth service system. } \\
\text { I am pleased with my use of mHealth service system. } \\
\text { I am delighted with my use of mHealth service system. }\end{array}$ & $\begin{array}{l}0.949 \\
0.952 \\
0.951 \\
0.934 \\
\end{array}$ & 0.971 & 0.895 \\
\hline $\begin{array}{l}\text { Continuance } \\
\text { Intentions }\end{array}$ & $\begin{array}{l}\text { I intend to continue using mHealth service system to get } \\
\text { medical information services. } \\
\text { My intention is to continue using this service system rather } \\
\text { than use any alternative means (e.g., going to local clinics) } \\
\text { I will not discontinue my use of this service system. }\end{array}$ & $\begin{array}{l}0.939 \\
0.924 \\
0.961 \\
\end{array}$ & 0.959 & 0.886 \\
\hline Quality of Life & $\begin{array}{l}\text { mHealth service system enabled me to improve my overall } \\
\text { health. } \\
\text { In most ways, my life has come closer to my ideal since I } \\
\text { started using this service system. } \\
\text { I have been more satisfied with my health life, thanks to } \\
\text { this service system. } \\
\text { So far, this service has helped me to achieve the } \\
\text { level of health I most want in life. }\end{array}$ & $\begin{array}{l}0.892 \\
0.905 \\
0.910 \\
0.871\end{array}$ & 0.941 & 0.800 \\
\hline
\end{tabular}


In Table 5, the study calculated the square root of the AVEs in the diagonals of the correlation matrix. These values exceed the intercorrelations of the construct with the other constructs in the first-order model and confirm discriminant validity (Chin, 1998b, 2010; Fornell and Lareker, 1981). This test indicates that the constructs do not share the same type of items and they are conceptually distinct from each other (Chin, 2010). In other words, each construct and its measures in the research model do a great job in discriminating themselves from other constructs and their corresponding measures. The study gains further confidence on discriminant validity by examining the cross-loadings, which indicate that items are more strongly related to their own construct than other constructs. In other words, each item loads more on its own construct than other constructs and, therefore, all constructs share a substantial amount of variance with their own items (Chin, 1998b; Fornell and Bookstein, 1982). In all cases, the item's relationship to its own construct has shared variance of more than $64 \%$ (i.e., $0.8 * 0.8$ ), which is substantial in magnitude in comparison with other constructs (Chin, 2010). Overall, the measurement model was considered satisfactory with the evidence of adequate reliability (AVE > 0.50, CR > 0.80) and convergent validity (loadings $>0.80)$ in Table 4 and discriminant validity $(\sqrt{A V E}>$ correlations) in Table 5. The first-order measurement model was thus confirmed satisfactory and was employed for testing the higher-order measurement model and the structural model in the next sections. 
Table 5: Descriptive Statistics, Correlations and AVEs*

\begin{tabular}{|c|c|c|c|c|c|c|c|c|c|c|c|c|c|c|c|}
\hline Construct & Mean & $S D$ & SYR & $S Y E$ & $S Y F$ & $S Y P$ & $R E S$ & $A S R$ & $E M P$ & $U T I$ & $H E I$ & $V A L$ & $S A T$ & $C O N$ & $Q O L$ \\
\hline $\begin{array}{l}\text { System } \\
\text { Reliability (SYR) }\end{array}$ & 5.713 & 1.124 & 0.918 & & & & & & & & & & & & \\
\hline $\begin{array}{l}\text { System } \\
\text { Efficiency (SYE) }\end{array}$ & 5.417 & 1.195 & 0.417 & 0.825 & & & & & & & & & & & \\
\hline $\begin{array}{l}\text { System } \\
\text { Flexibility (SYF) }\end{array}$ & 5.521 & 1.175 & 0.419 & 0.418 & 0.933 & & & & & & & & & & \\
\hline $\begin{array}{l}\text { System } \\
\text { Privacy (SYP) }\end{array}$ & 5.265 & 1.238 & 0.282 & 0.454 & 0.451 & 0.944 & & & & & & & & & \\
\hline $\begin{array}{l}\text { Responsiveness } \\
\text { (RES) }\end{array}$ & 5.923 & 1.129 & 0.395 & 0.383 & 0.393 & 0.311 & 0.908 & & & & & & & & \\
\hline Assurance (ASR) & 5.612 & 1.238 & 0.427 & 0.394 & 0.370 & 0.438 & 0.370 & 0.876 & & & & & & & \\
\hline Empathy (EMP) & 5.756 & 1.163 & 0.381 & 0.451 & 0.349 & 0.404 & 0.449 & 0.363 & 0.915 & & & & & & \\
\hline Utilitarian (UTI) & 5.767 & 1.028 & 0.303 & 0.467 & 0.369 & 0.398 & 0.385 & 0.450 & 0.382 & 0.829 & & & & & \\
\hline Hedonic (HEI) & 5.586 & 1.232 & 0.418 & 0.458 & 0.461 & 0.365 & 0.397 & 0.407 & 0.482 & 0.468 & 0.952 & & & & \\
\hline Value (VAL) & 5.576 & 1.114 & 0.441 & 0.333 & 0.451 & 0.374 & 0.463 & 0.474 & 0.414 & 0.410 & 0.402 & 0.921 & & & \\
\hline $\begin{array}{l}\text { Satisfaction } \\
(\mathrm{SAT})\end{array}$ & 5.640 & 1.127 & 0.328 & 0.433 & 0.501 & 0.340 & 0.391 & 0.396 & 0.316 & 0.418 & 0.410 & 0.481 & 0.946 & & \\
\hline $\begin{array}{l}\text { Continuance } \\
(\mathrm{CON})\end{array}$ & 5.590 & 1.285 & 0.447 & 0.399 & 0.448 & 0.324 & 0.487 & 0.303 & 0.403 & 0.381 & 0.463 & 0.419 & 0.421 & 0.941 & \\
\hline $\begin{array}{l}\text { Quality of life } \\
\text { (QOL) }\end{array}$ & 5.492 & 1.134 & 0.444 & 0.443 & 0.489 & 0.382 & 0.310 & 0.362 & 0.389 & 0.380 & 0.462 & 0.447 & 0.340 & 0.371 & 0.894 \\
\hline
\end{tabular}

*square root of the AVE on the diagonal 


\subsection{Higher-Order Measurement Model}

In Table 6, the study estimated measurement properties of higher-order constructs, that is, the third-order SSQ construct and second-order system quality, interaction quality and information quality constructs. The third-order mHealth service quality construct consists of 27 items $(12+$ $9+6)$ in which 12 items $(3+3+3+3)$ represent system quality, 9 items $(3+3+3)$ represent interaction quality and 6 items $(3+3)$ represent information quality. Since higher-order constructs are formative, therefore, the study confirmed that the weights of items of both the third-order SSQ construct and the second-order constructs (system quality, interaction quality and information quality) are significant at $\mathrm{p}<0.05$. We also conducted a collinearity test on the index and the results provide evidence of minimum collinearity among the formative items as the variance inflation factor (VIF) of all items range between 1.095 to 1.232 , far below the common cut-off threshold of 5 to 10.

Table 6: Assessment of the Higher-Order, Formative Model

\begin{tabular}{|c|c|c|c|c|c|c|}
\hline $\begin{array}{l}\text { Third-order } \\
\text { Formative construct }\end{array}$ & $\begin{array}{l}\text { Weights } \\
\text { of items* }\end{array}$ & p-value & VIF & $\begin{array}{l}\text { Relationships with } \\
\text { second-order dimensions }\end{array}$ & $\beta$ & t-stat \\
\hline $\begin{array}{l}\text { Service system } \\
\text { quality }\end{array}$ & $\begin{array}{l}0.112- \\
0.243\end{array}$ & $P<0.05$ & $1.12-1.60$ & $\begin{array}{l}\text { System quality } \\
\text { Interaction quality } \\
\text { Information quality }\end{array}$ & $\begin{array}{l}0.204 \\
0.253 \\
0.603\end{array}$ & $\begin{array}{l}3.781 \\
3.409 \\
9.272\end{array}$ \\
\hline $\begin{array}{l}\text { Second-order } \\
\text { Formative constructs }\end{array}$ & Weights & p-value & VIF & $\begin{array}{l}\text { Relationships with first- } \\
\text { order dimensions }\end{array}$ & $\beta$ & t-stat \\
\hline System quality & $\begin{array}{l}0.112- \\
0.243\end{array}$ & $\mathrm{P}<0.05$ & $1.15-1.85$ & $\begin{array}{l}\text { System reliability } \\
\text { System efficiency } \\
\text { System flexibility } \\
\text { System privacy }\end{array}$ & $\begin{array}{l}0.415 \\
0.301 \\
0.419 \\
0.180\end{array}$ & $\begin{array}{l}5.957 \\
4.614 \\
5.338 \\
2.516 \\
\end{array}$ \\
\hline Interaction quality & $\begin{array}{l}0.105- \\
0.326\end{array}$ & $\mathrm{P}<0.05$ & $1.20-1.50$ & $\begin{array}{l}\text { Responsiveness } \\
\text { Assurance } \\
\text { Empathy }\end{array}$ & $\begin{array}{l}0.238 \\
0.691 \\
0.182\end{array}$ & $\begin{array}{l}2.623 \\
10.801 \\
2.249 \\
\end{array}$ \\
\hline Information quality & $\begin{array}{l}0.131- \\
0.330\end{array}$ & $\mathrm{P}<0.05$ & $1.13-1.30$ & $\begin{array}{l}\text { Utilitarian } \\
\text { Hedonic }\end{array}$ & $\begin{array}{l}0.574 \\
0.486\end{array}$ & $\begin{array}{l}8.627 \\
7.279\end{array}$ \\
\hline
\end{tabular}

*weights of items of the higher-order formative construct, i.e., third-order service system quality (27 items) and second-order system quality (12 items), interaction quality ( 9 items) and information quality (6 items). 
The degree of explained variance of the third-order mHealth SSQ construct was explained by its second-order antecedents, that is, system quality (20\%), interaction quality (25\%), and information quality (60\%). Accordingly, variances of the second-order constructs were explained by its corresponding first-order antecedents. For example, the degree of explained variance of system quality was explained by system reliability (42\%), system efficiency (30\%), system

flexibility (42\%) and system privacy (18\%). Similarly, interaction quality was explained by responsiveness (24\%), assurance (69\%) and empathy (18\%). And finally, information quality was explained by utilitarian (57\%) and hedonic information quality (49\%). All these path coefficients from the first-order to second-order to third-order constructs were significant at $\mathrm{p}<$ 0.05. Since the second-order and the third-order constructs are formative in nature and we have used the repeated indicator approach, the estimation has resulted into a $R^{2}$ value of unity for the highest-order construct (Becker et al., 2012b; Wetzels et al., 2009). In other words, SSQ has resulted into $\mathrm{R}^{2}=1.0$ because the second-order formative constructs already explain all the variance of the third-order formative SSQ construct.

\subsection{Structural Model}

To assess the validity of the structural model, the study estimated the relationship between higher-order SSQ, VAL, SAT, CON and QOL. In Figure 3, the results provided a standardized beta of 0.799 (SSQ-VAL), 0.394 (VAL-SAT), 0.144 (VAL-CON) and 0.262 (SSQ-CON) respectively. All these path coefficients were significant at $\mathrm{p}<0.05$ (see Table 7). Thus, the study confirmed that quality of overall mHealth service system has a significant positive impact on VAL, SAT and CON, supporting H1, H2, H3 \& H4. 


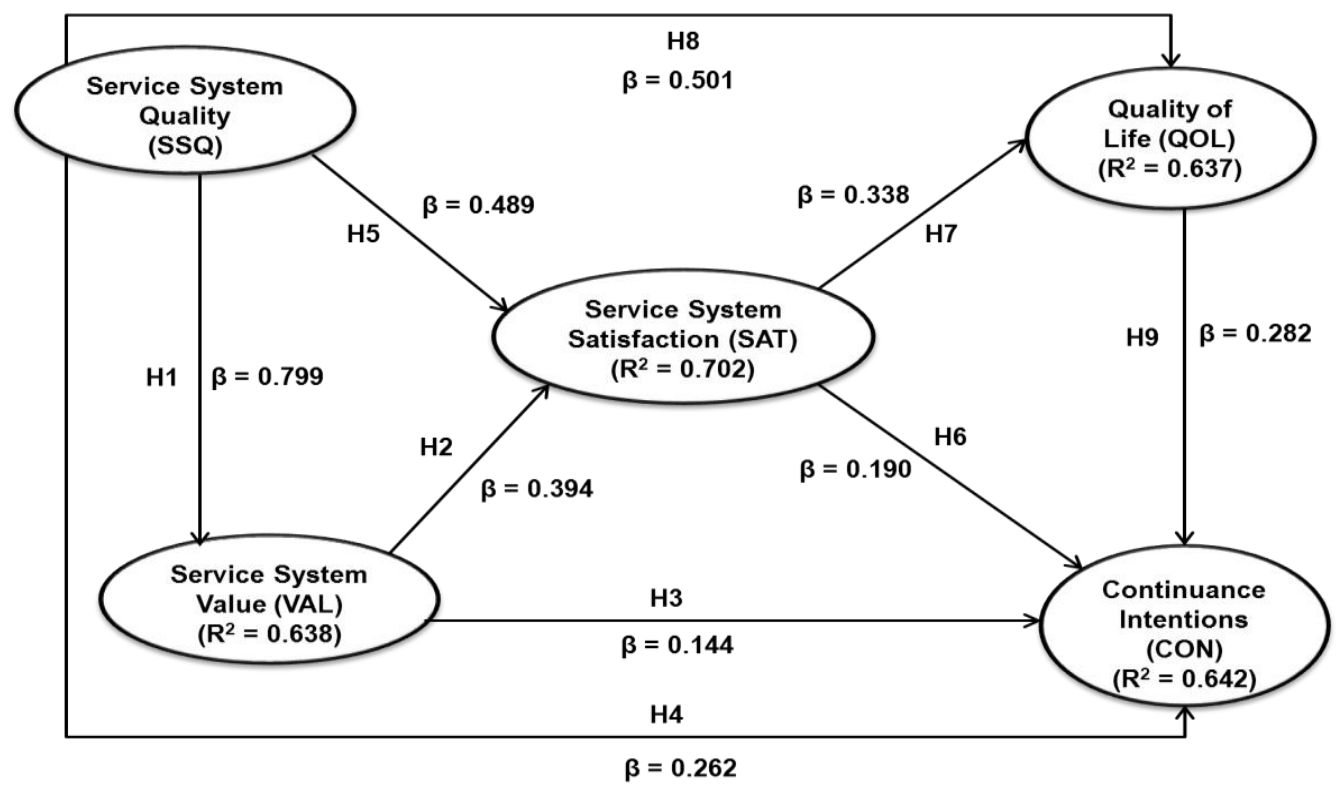

Figure 3 Structural model

Similarly, higher-order SSQ has a significant positive impact on SAT, CON and QOL. In Figure 3, the results provided a standardized beta of 0.489 (SSQ-SAT), 0.190 (SAT-CON), 0.338 (SATQOL), 0.501 (SSQ-QOL) and 0.282 (QOL-CON). The results confirmed that the path coefficients between SSQ-SAT-QOL-CON were significant at $\mathrm{p}<0.01$ (see Table 7). These relationships confirmed that quality of mHealth service system has a significant positive impact on SAT, QOL and CON. Thus, the study found support for H5-H9.

Table 7 Results of structural model

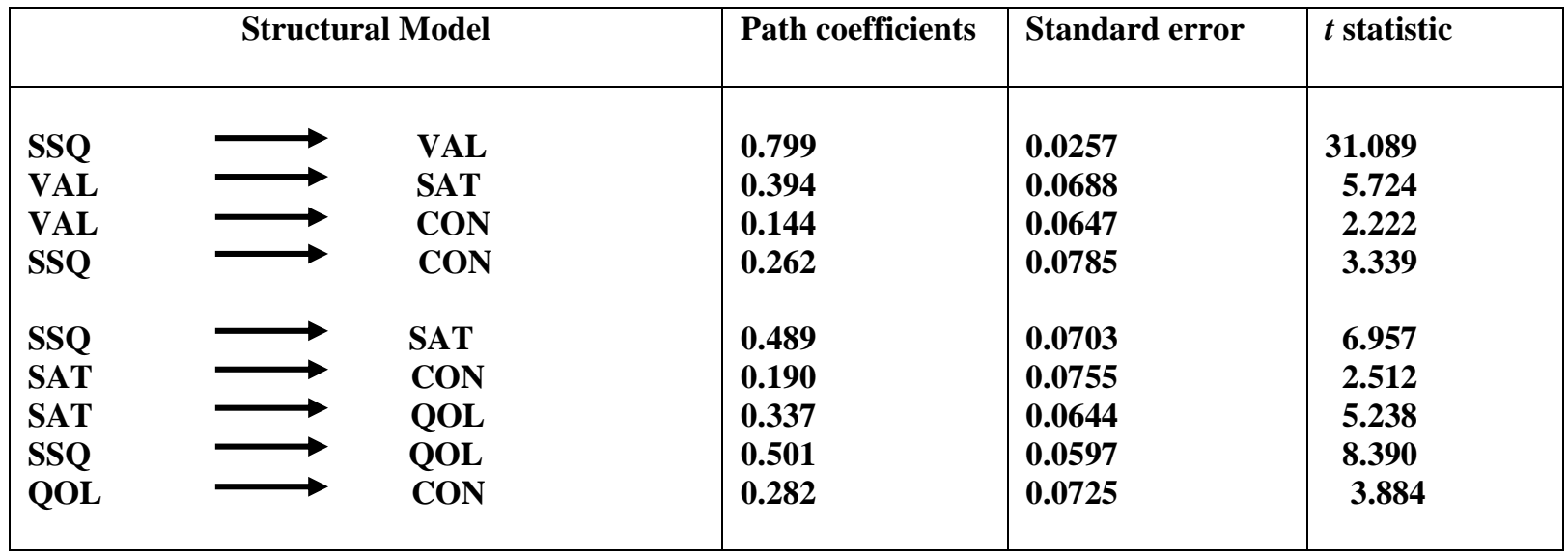


The study also analyzes the indirect (or, mediating) effect of value on both SSQ-VAL-SAT link and SSQ-VAL-CON link. The results confirm the strong mediating effects of VAL in SSQVAL-SAT link and SSQ-VAL-CON link as the $z$-value exceeds 1.96 (p < 0.05) (Iacobucci, 2008; Sobel, 1982).These findings support H10.1 and H10.2. Similarly, the findings confirm the significant mediating effects of SAT in the SSQ-SAT-QOL link and SSQ-SAT-CON link, supporting H11.1 and H11.2. To estimate size of the indirect effect, this study uses the VAF (Variance Accounted For) value, which represents the ratio of the indirect effect to the total effect (Hair Jr et al., 2013). The results indicate that VAL explains about $39 \%$ of the total effect of SSQ on SAT and about $31 \%$ on CON. Similarly, SAT explains about $25 \%$ of the total effect of SSQ on QOL and $26 \%$ on CON. Therefore, both VAL and SAT have been proven as significant mediators in estimating the effects of overall service quality on service outcomes. The overall variance explained by the model in terms of $\mathrm{R}^{2}$ was 0.638 for VAL, 0.702 for SAT, 0.637 for QOL and 0.642 for CON, which were significantly large $\left(f^{2}>0.35\right)$ according to the effect sizes defined for $R^{2}$ by Cohen (Cohen, 1988). These results confirm the impact of overall service systems quality on perceived value, satisfaction, continuance intentions and quality of life, thereby ensuring nomological validity of the overall research model.

\subsection{Additional Analyses}

First, in order to address the concern of common method variance (CMV) from a single source of data, the study applied Harman's one-factor test (Podsakoff and Organ, 1986) on 13 first-order constructs and the test did not find any significant bias in the dataset because there was no common factor loading on all the measures. However, this test was criticized by Podsakoff (Podsakoff et al., 2003) due to lack of sensitivity, thus we applied another procedure recommended by Widaman (1985) and Podsakoff et al. (2003) by taking into account the method 
factor in the model. However, the results did not show any significant increase in the variance and all factor loadings of the traits were still significant after including common method factor. Second, the study estimated the goodness of fit index (GoF) (Tenenhaus et al., 2005), which is 0.75 and adequately established the global validity of the quality model.

\section{DISCUSSION}

\subsection{Summary of Findings}

This study developed a higher-order SSQ model consisting of three primary dimensions and nine subdimensions. The SSQ model was developed to capture quality dynamics in a transformative service system by conceptualizing the dimensions of quality and framing its impact on service outcomes in a nomological network. The findings show that higher order SSQ in mHealth service systems has a strong significant impact on SAT, VAL, QOL and CON. This finding highlights that the emphasis on quality is the perfect starting point for identifying and solving emerging service systems challenges (Alter, 2010). These findings also put forward the concept of 'customer centricity' in visualizing system related problems in the broader service systems research.

SSQ was found to have a positive association with all the primary dimensions with 'information quality' emerging as the strongest. This finding suggests that greater gains in overall SSQ can be achieved by useful information provision. Then 'interaction quality' was identified as a significant dimension which indicates that any service system must be responsive to the real time needs of the users. Finally, 'system quality' was identified as a key predictor of mHealth service system, which emphasizes right time availability of the system so that anyone can receive health services at anytime from anywhere. In low resource settings this ubiquity is critical in enabling 
the patient outcomes of mHealth service systems. Although the study has prioritized the importance of overall SSQ dimensions in terms of explained variance, the study recommends that equal attention should be paid to all the dimensions to adequately embrace quality in service systems research.

The structural model findings confirm that SSQ is a significant predictor of VAL (explaining $64 \%$ of the variance). These findings confirm S-D logic, implying that exchange processes in the service sector should prioritize VAL and SAT for enhancing QOL and promoting CON. These findings also confirm that SAT and VAL are the key mediators or, the necessary conditions for strong QOL and CON. Overall, these findings suggest that service system should consider 'SSQ' as an important strategic objective to predict VAL, SAT, QOL and CON. Overall, the findings also stress the importance of SSQ and underscore the recent wave of research in service systems investigating the construct.

\subsection{Contribution to Theory}

Although an increasing body of literature emphasizes the importance of S-D logic and sociomaterialism in service systems research, the operationalization of the concepts remains theoretical (Karpen et al., 2015). This study advances service systems research by applying the entanglement view of sociomaterialism in conceptualizing quality and S-D logic in modeling its effects on service outcomes (i.e., VAL, SAT, CON \& QOL) in a nomological net, which have not been investigated before. The findings of the study develop and validate a higher-order quality model with three primary dimensions: systems quality; interaction quality; information quality. The nine sub-dimensions of the model are: systems reliability; systems efficiency; systems flexibility; systems privacy; responsiveness; assurance; empathy; utilitarian and hedonic information. The parsimonious structure of the SSQ model and its combined explanatory power 
advance quality logic in service systems research. Specifically, the study contributes in severat ways: to quality research in the service systems domain. firstly, the study defines the domain of three primary SSQ constructs, nine sub-constructs and their associated measurement items against the backdrop of QD research in service systems. Secondly, the study identifies a comprehensive, yet parsimonious, set of dimensions that help predict SSQ of an emerging service system and their association with outcome constructs (i.e., VAL, SAT, CON and QOL). Thirdly, specific characteristics of mHealth service systems are explored providing possible solutions to the challenges of this emerging domain of service systems. The study extends $S-D$ logic and sociomaterialism by capturing quality in service systems research and framing its impact on critical outcome constructs (VAL, SAT, CON \& QOL) in a nomølogical net, which have not been investigated before.

Specifically, first, the study extends entanglement view by developing a third-order SSQ model, which shows that the individual quality dimension forms the global SSQ model. This viewpoint argues that the physical (i.e., technology platform), informational (i.e., hedonic or utilitarian value) and human (e.g., interaction skills) dimensions of SSQ are inextricably related (Orlikowski and Scott, 2008). The findings prove that they are mutually supportive and act together to achieve a synergistic result. Second, using S-D logic, the study shows the impact of SSQ on individual (i.e., value, satisfaction), economic (i.e., continuance) and social (i.e., QOL) outcomes in a transformative service system research. It is apparent that transformative service system, such as mHealth, need to move beyond traditional individual and financial measures and embrace the social outcomes. As such, conceptualization and evaluation of QOL are significant because QOL is not well understood as an outcome of service systems despite a growing focus on the relationship and the impact of service systems research on society (Ostrom et al., 2015a). 
This assessment is a direct contribution to S-D logic as it explores the role of quality on critical service outcomes in the context of emerging service systems research. These associations are important as the global economy is becoming characterized by services. The findings of the study thus address Ostrom et al.'s (2010, p.32) concerns, that is, “... service is not only about increasing revenues and profits at for-profit firms but also about how to advance service in a way that delivers higher-order, societal outcomes".

Finally, the study adds further theoretical rigor by analyzing the indirect effects of value and satisfaction on service outcome constructs. In this context, Iacobucci (Iacobucci, 2009, p.673) states "If mediation clarifies the conceptual picture somewhat, with the insertion of just one new construct — the mediator - imagine how much richer the theorizing might be if researchers tried to formulate and test even more complex nomological networks". The theory also embraces its uniqueness by conceptualizing quality in a new setting (i.e., a developing country) based on the logical evidence of perceived entanglement view. Although quality research has proven to be instrumental for the success of service systems in the developed world, there are few studies which have designed models to serve developing countries (Lucas Jr et al., 2013). It is worth noting that developing countries represent more than four billion people and the concept of designing economically-viable and socially-responsible service systems to serve this majority of the world's population has gained increased attention (Hart and Prahalad, 2002; London, 2009; Prahalad, 2009; Prahalad and Hammond, 2002). Thus, the study extends quality research for a transformative service system in developing countries in order to scale and sustain this platform. In this regard, Whetten (1989, p.493) states that, "the common element in advancing theory development by applying it in new settings ... that is, new applications should improve the tool, not merely reaffirm its utility". In a similar spirit, the study believes that the proposed theoretical 
framework extends knowledge as most of its constructs and their relationships have not been the subject of prior theorizing in this context. It also opens up a new horizon in the emerging service systems research that will bring fascinating new perspectives to the field. As Straub states (Straub, 2009, p.vi) "[o]nce a theme has been introduced into the field, the resonance of the theme within the field spurs new work".

\subsection{Contribution to Practice}

The model in this study may be prescriptive for the managers and designers of service systems as well as for society in general. The findings indicate that the improvements of overall quality can be attributed to the constructs on the sub dimensional level, such as, systems reliability, systems availability, systems efficiency, systems privacy, responsiveness, assurance; empathy, utilitarian and hedonic information. These findings illustrate for management the connection between the hierarchies in the model thus enabling their understanding of the relationship between the quality constructs. As an example, perceptions of system quality may be enhanced by improving the systems reliability, systems efficiency, systems availability and systems privacy. Similarly, interaction quality may be improved by enhancing the customer experience with sincere and genuine responses; an empathetic attitude and adequate assurance. Information quality may be enhanced by customers of utilitarian and hedonic benefits of the service system, i.e., convenience; fulfillment; positive support which are benefits of the transformative service system.

The model and findings provide managers with a diagnostic tool for analyzing and identifying issues of service delivery. It is clear that system quality, interaction quality and information quality are not isolated constructs. Optimal outcomes for service quality are dependent on appropriate levels being delivered on the three dimensions. Coordination of all the constructs by 
management is necessary to deliver quality outcomes of a system, of interactions between patients and the systems and, importantly, the quality of information which is part of the service system thus providing valuable insights on the contribution of each individual sub-dimension to the overall service system quality.

The linkages illustrated above of the constructs in the model provide managers with an understanding of the antecedents of SSQ by linking individual quality dimension with overall service quality, which in turn drive perception of value (VAL), satisfaction (SAT), quality of life (QOL) and continuance intentions (CON). The findings of the study provide evidence for the importance of quality as a variable in decision making processes in predicting individual (VAL \& SAT), economic (CON) and social (QOL) outcomes of service systems. Recent studies in the literature have demonstrated that continuance is the significant variable when considering consumers' intention to continue using a service system. Therefore the scalability of a transformative service system may be enabled by the findings on 'continuance' and its antecedents: SSQ; VAL; SAT; and QOL. The findings also provide managers with a number of metrics to measure the success of a transformative service system as users move beyond initial adoption to continued use. Further, through QOL assessment, a tool is now provided to management to track externalities in terms of societal welfare brought about by mHealth implementations. Modelling QOL is a new paradigm in this stream of research as it ensures sustainability of a transformative service system. The strong mediating role of 'VAL' and 'SAT' in predicting $\mathrm{CON}$ and QOL suggest that managers should consider 'VAL' and 'SAT' as important strategic objectives to ensure better quality of health life perception and positive continuance intentions. Therefore the SSQ model proposed in this study may assist providers in enabling strategic outcomes such as client loyalty; improved health outcomes for patients and 
importantly societal and global benefits of improved quality of life. Organizations (private, public, non-government organizations and regional, national and global) may utilize the findings from such transformative service systems research to formulate strategy, measure outcomes and contribute to the greater global good.

The findings of the study extend the scope of service systems research for practitioners by modeling the impact of SSQ on service outcomes through an expanded theory-based framework. The findings provide critical insights to practitioners on key antecedents, mediating and outcome variables which are fundamental to scale and sustain a service system. These findings will certainly create efficiencies within mHealth service systems by positively influencing health eutcemes.According to (Jia et al., 2008, p.311), "[e]quipped with a deeper understanding of the IT service quality phenomenon, IT managers will be enabled to improve customer service, increase customer satisfaction, and achieve stronger business-IT alignment". This research also contributes to important service quality decisions across the globe in mHealth, which could guide the formulation and use of service systems policy in national welfare. Overall, the findings on quality dynamics will help practitioners improve the mHealth service systems by facilitating continuance, enhancing workflow and promoting evidence-based practice to make informed and effective decisions directly at the point of care.

\subsection{Limitations}

Several limitations are worth noting. Firstly, in terms of generalizability the research was conducted in one country, even though service quality is context specific replicating the study in other countries would add to the validity of the model. Secondly, the study is limited by the approach to data collection: cross- sectional design consequently the current research represents the static approach of service evaluation. This may be addressed by future longitudinal study 
evaluating users' perceptions and their evaluation of mHealth service quality over time. The final limitation being that the sample is drawn from a population in a developing country, Bangladesh. Therefore generalizability to users from developed economies is limited. Furthermore, national culture may play some role in the perception of the components and consequences of quality logic in Eastern and Western cultures, developing and developed countries and individualistic and collectivist communities.

\subsection{Future Research Directions}

The present study identifies mHealth as a transformative health service system, which dynamically configures people, technology, organization and information resources (Maglio et al., 2015). Thus, an interesting avenue for research in this domain is how to exploit and disrupt resources in influencing quality dynamics and relevant outcomes. In addition, there is a research call to explore how different entities in such service systems could compute value to ensure the economic and social sustainability of business model. Furthermore, because of the complex nature of human behavior and IT interaction in service systems, there is a growing emphasis on examining the trends and challenges in an interdisciplinary manner. This presents an amazing opportunity for collaboration between industry and academics for transformative service systems research. The leading industry players such as IBM, Intel, Unisys, Oracle, and other have already started deriving the benefits of this collaboration by embracing service oriented thinking and quality dominant decision making. Overall, it is widely believed that quality viewpoint will vitalize research into wide scale interoperability (e.g., cloud computing, service-oriented architecture, web services, systems as a service). It will also facilitate service systems to reconcile with mainstream service research notions. Advancing this reconciliation of currently 
disparate research streams remains an important research priority for service science in the foreseeable future.

\section{CONCLUSION}

To conclude, this study empirically validated the effect of quality logic on satisfaction, value, quality of life and continuance intentions of a service system. The findings of the study confirm the critical role of quality dynamics and their impact on individual, social and economic outcomes in the context of a transformative mHealth service system. Overall, while the findings of the study identify the hierarchical nature of service systems quality and its direct impact on outcome constructs, they also show that the indirect effects of quality are conditional on the level of perceived value and satisfaction. These findings on quality dynamics should help managers in designing, developing, and deploying a transformative service system for mutual benefits of providers and consumers. The findings also offer an important step on the path to providing conceptual clarity and practical solutions to the quality modeling in service systems studies.

\section{REFERENCES}

Aharony, L., Strasser, S., 1993. Patient satisfaction: what we know about and what we still need to explore. Medical care review.

Ajzen, I., Fishbein, M., 1980. Understanding attitudes and predicting social behaviour.

Akter, S., Ray, P., 2010. mHealth-an Ultimate Platform to Serve the Unserved. Yearbook of medical informatics, 94.

Akter, S., Ray, P., D'Ambra, J., 2013. Continuance of mHealth services at the bottom of the pyramid: the roles of service quality and trust. Electronic Markets 23, 29-47.

Alter, S., 2010. Viewing systems as services: a fresh approach in the IS field. Communications of the Association for Information Systems 26.

Andaleeb, S.S., 2000. Public and private hospitals in Bangladesh: service quality and predictors of hospital choice. Health Policy and Planning 15, 95-102.

Andaleeb, S.S., 2001. Service quality perceptions and patient satisfaction: a study of hospitals in a developing country. Social science \& medicine 52, 1359-1370. 
Andaleeb, S.S., 2008. Caring for children: a model of healthcare service quality in Bangladesh. International Journal for Quality in Health Care 20, 339-345.

Anderson, L., Ostrom, A.L., 2015. Transformative Service Research: Advancing Our Knowledge About Service and Well-Being. Journal of Service Research 18, 243-249.

Anderson, L., Ostrom, A.L., Corus, C., Fisk, R.P., Gallan, A.S., Giraldo, M., Mende, M., Mulder, M., Rayburn, S.W., Rosenbaum, M.S., 2012. Transformative service research: An agenda for the future. Journal of Business Research.

Athanassopoulos, A.D., 2000. Customer satisfaction cues to support market segmentation and explain switching behavior. Journal of Business Research 47, 191-207.

Babakus, E., Boller, G.W., 1992. An empirical assessment of the SERVQUAL scale. Journal of Business Research 24, 253-268.

Bagozzi, R.P., 2011. Measurement and meaning in information systems and organizational research: methodological and philosophical foundations. MIS Quarterly 35, 261-292.

Bansal, H.S., Taylor, S.F., St James, Y., 2005. "Migrating" to new service providers: Toward a unifying framework of consumers' switching behaviors. Journal of the Academy of Marketing Science 33, 96-115.

Bardhan, I.R., Demirkan, H., Kannan, P.K., Kauffman, R., Sougstad, R., 2010a. An interdisciplinary perspective on IT services management and service science. Journal of Management Information Systems 26, 13-64.

Bardhan, I.R., Demirkan, H., Kannan, P.K., Kauffman, R.J., Sougstad, R., 2010b. An Interdisciplinary Perspective on IT Services Management and Service Science. Journal of Management Information Systems 26, 13-64.

Barile, S., Polese, F., 2010. Smart service systems and viable service systems: Applying systems theory to service science. Service Science 2, 21-40.

Baron, R.M., Kenny, D.A., 1986. The moderator-mediator variable distinction in social psychological research: conceptual, strategic and statistical considerations. Journal of personality and social psychology 51, 1173-1182.

Becker, J.-M., Klein, K., Wetzels, M., 2012a. Hierarchical latent variable models in PLSSEM: guidelines for using reflective-formative type models. Long Range Planning.

Becker, J.-M., Klein, K., Wetzels, M., 2012b. Hierarchical latent variable models in PLSSEM: guidelines for using reflective-formative type models. Long Range Planning 45, 359-394.

Becker, J., Beverungen, D.F., Knackstedt, R., 2010. The challenge of conceptual modeling for product-service systems: status-quo and perspectives for reference models and modeling languages. Information Systems and E-Business Management 8, 33-66.

Bhattacherjee, A., 2001. Understanding information systems continuance: an expectationconfirmation model. MIS Quarterly 25, 351-370.

Bhattacherjee, A., Premkumar, G., 2004. Understanding changes in belief and attitude toward information technology usage: a theoretical model and longitudinal test. MIS Quarterly 28, 229254.

Bitner, M.J., 1990. Evaluating service encounters: the effects of physical surroundings and employee responses. the Journal of Marketing, 69-82.

Bloomberg, L.P., 2015. China Services Growth Picks Up in Sign Economy Stabilizing Retrieved August 26.

Boulding, W., Kalra, A., Staelin, R., Zeithaml, V.A., 1993. A dynamic process model of service quality: from expectations to behavioral intentions. Journal of Marketing Research 30, 7 27. 
Brady, M.K., Cronin, J.J., 2001. Some new thoughts on conceptualizing perceived service quality: a hierarchical approach. the Journal of Marketing, 34-49.

Brady, M.K., Robertson, C.J., 2001. Searching for a consensus on the antecedent role of service quality and satisfaction: an exploratory cross-national study. Journal of Business Research 51, 53-60.

Calabrese, A., 2012. Service productivity and service quality: A necessary trade-off? International Journal of Production Economics 135, 800-812.

Caruana, A., Ewing, M.T., Ramaseshan, B., 2000. Assessment of the three-column format SERVQUAL: an experimental approach. Journal of Business Research 49, 57-65.

Chatterjee, S., Chakraborty, S., Sarker, S., Sarker, S., Lau, F.Y., 2009. Examining the success factors for mobile work in healthcare: A deductive study. Decision Support Systems 46, 620633.

Chin, W.W., 1998a. Commentary: Issues and opinion on structural equation modeling. MIS Quarterly.

Chin, W.W., 1998b. The partial least squares approach for structural equation modeling.

Chin, W.W., 2010. How to write up and report PLS analyses. Handbook of partial least squares, 655-690.

Chiou, J.-S., Droge, C., 2006. Service quality, trust, specific asset investment, and expertise: direct and indirect effects in a satisfaction-loyalty framework. Journal of the Academy of Marketing Science 34, 613-627.

Choi, H., Lee, M., Im, K.S., Kim, J., 2007. Contribution to quality of life: a new outcome variable for mobile data service. Journal of the Association for Information Systems 8, 598-618.

Choi, K.-S., Cho, W.-H., Lee, S., Lee, H., Kim, C., 2004. The relationships among quality, value, satisfaction and behavioral intention in health care provider choice: a South Korean study. Journal of Business Research 57, 913-921.

Cohen, J., 1988. Statistical power analysis for the behavioral sciences. Routledge Academic.

Cronin, J.J., Brady, M.K., Brand, R.R., Hightower Jr, R., Shemwell, D.J., 1997. A crosssectional test of the effect and conceptualization of service value. Journal of services Marketing $11,375-391$.

Cronin, J.J., Taylor, S.A., 1992. Measuring service quality: a reexamination and extension. the Journal of Marketing, 55-68.

Crosby, P.B., 1984. Quality without tear: the art of hassle-free management. McGraw-Hill, New York.

D’Ambra, J., Rice, R.E., 2001. Emerging factors in user evaluation of the World Wide Web. Information \& Management 38, 373-384.

Dagger, T.S., Sweeney, J.C., 2006. The effect of service evaluations on behavioral intentions and quality of life. Journal of Service Research 9, 3-18.

Dagger, T.S., Sweeney, J.C., Johnson, L.W., 2007. A hierarchical model of health service quality scale development and investigation of an integrated model. Journal of Service Research 10, 123-142.

Davis, F.D., 1989. Perceived usefulness, perceived ease of use, and user acceptance of information technology. MIS Quarterly, 319-340.

Delone, W.H., 2003. The DeLone and McLean model of information systems success: a tenyear update. Journal of Management Information Systems 19, 9-30.

DeLone, W.H., McLean, E.R., 1992. Information systems success: the quest for the dependent variable. Information Systems Research 3, 60-95. 
Dey, P.K., Bhattacharya, A., Ho, W., 2015. Strategic supplier performance evaluation: A case-based action research of a UK manufacturing organisation. International Journal of Production Economics 166, 192-214.

Dominguez-Péry, C., Ageron, B., Neubert, G., 2013. A service science framework to enhance value creation in service innovation projects. An RFID case study. International Journal of Production Economics 141, 440-451.

Edvardsson, B., Tronvoll, B., Gruber, T., 2011. Expanding understanding of service exchange and value co-creation: a social construction approach. Journal of the Academy of Marketing Science 39, 327-339.

Edwards, J.R., 2001. Multidimensional constructs in organizational behavior research: An integrative analytical framework. Organizational Research Methods 4, 144-192.

Efron, B., Tibshirani, R., 1993. An introduction to the bootstrap. Chapman \& Hall/CRC.

Endres, A., 1999. Utility theory. The Elgar Companion to Consumer Research and Economic Psychology, 599-604.

Fassnacht, M., Koese, I., 2006. Quality of electronic services conceptualizing and testing a hierarchical model. Journal of Service Research 9, 19-37.

Ferrans, C.E., Powers, M.J., 1992. Psychometric assessment of the Quality of Life Index. Research in nursing \& health 15, 29-38.

Fornell, C., Bookstein, F.L., 1982. Two structural equation models: LISREL and PLS applied to consumer exit-voice theory. Journal of Marketing Research, 440-452.

Fornell, C., Johnson, M.D., Anderson, E.W., Cha, J., Bryant, B.E., 1996. The American customer satisfaction index: nature, purpose, and findings. the Journal of Marketing, 7-18.

Fornell, C., Larcker, D.F., 1981. Evaluating structural equation models with unobservable variables and measurement error. Journal of Marketing Research, 39-50.

Gefen, D., Karahanna, E., Straub, D.W., 2003. Trust and TAM in online shopping: an integrated model. MIS Quarterly, 51-90.

Golder, P.N., Mitra, D., Moorman, C., 2012. What is quality? an integrative framework of processes and states. Journal of Marketing 76, 1-23.

Gregor, S., 2006. The nature of theory in information systems. MIS Quarterly 30, 611-642.

Gronroos, C., 2000. Creating a relationship dialogue: communication, interaction and value. The marketing review 1, 5-14.

Grönroos, C., 1984. A service quality model and its marketing implications. European Journal of Marketing 18, 36-44.

Gummesson, E., 1991. Marketing-orientation revisited: the crucial role of the part-time marketer. European Journal of Marketing 25, 60-75.

Hair, J.F., Ringle, C.M., Sarstedt, M., 2011. PLS-SEM: Indeed a silver bullet. The Journal of Marketing Theory and Practice 19, 139-152.

Hair Jr, J.F., Hult, G.T.M., Ringle, C., Sarstedt, M., 2013. A primer on partial least squares structural equation modeling (PLS-SEM). Sage Publications.

Hallikas, J., Immonen, M., Pynnönen, M., Mikkonen, K., 2014. Service purchasing and value creation: Towards systemic purchases. International Journal of Production Economics 147, Part A, 53-61.

Hart, S., Prahalad, C., 2002. The Fortune at the Bottom of the Pyramid. Strategy+ Business 26, 54-67. 
Hawkins, T.G., Gravier, M.J., Berkowitz, D., Muir, W.A., 2015. Improving services supply management in the defense sector: How the procurement process affects B2B service quality. Journal of Purchasing and Supply Management 21, 81-94.

Huang, M.-H., Rust, R.T., 2013. IT-Related Service: A Multidisciplinary Perspective. Journal of Service Research 16, 251-258.

Hulland, J., Ryan, M.J., Rayner, R.K., 2010. Modeling customer satisfaction: a comparative performance evaluation of covariance structure analysis versus partial least squares, Handbook of partial least squares. Springer, pp. 307-325.

Iacobucci, D., 2008. Mediation analysis. Sage.

Iacobucci, D., 2009. Everything you always wanted to know about SEM (structural equations modeling) but were afraid to ask. Journal of Consumer Psychology 19, 673-680.

IfM, IBM, 2007. Succeeding through service innovation: A discussion paper. University of Cambridge Institute for Manufacturing, Cambridge, United Kingdom.

Inglehart, R., Rabier, J.-R., 1986. Aspirations adapt to situations-but why are the Belgians so much happier than the French? A cross-cultural analysis of the subjective quality of life. Research on the Quality of Life. Ann Arbor: Institute for Social Research University of Michigan.

Jarvis, C.B., MacKenzie, S.B., Podsakoff, P.M., 2003. A critical review of construct indicators and measurement model misspecification in marketing and consumer research. Journal of consumer research 30, 199-218.

Jia, R., Reich, B.H., Pearson, J.M., 2008. IT service climate: An extension to IT service quality research. Journal of the Association for Information Systems 9, 13.

Jiang, J.J., Klein, G., Crampton, S.M., 2000. A note on SERVQUAL reliability and validity in information system service quality measurement. Decision Sciences 31, 725-744.

Kalakota, R., Robinson, M., 2001. E-business 2.0: Roadmap for Success. Addison-Wesley Professional.

Kallinikos, J., 2007. The consequences of information: Institutional implications of technological change. Edward Elgar Publishing.

Karahanna, E., Straub, D.W., Chervany, N.L., 1999. Information technology adoption across time: a cross-sectional comparison of pre-adoption and post-adoption beliefs. MIS Quarterly 23, 183-213.

Karpen, I.O., Bove, L.L., Lukas, B.A., Zyphur, M.J., 2015. Service-Dominant Orientation: Measurement and Impact on Performance Outcomes. Journal of Retailing 91, 89-108.

Kasper, H., Van Helsdingen, P., De Vries, W., 1999. Services marketing management: an international perspective. Wiley New York, NY.

Kettinger, W.J., Lee, C.C., 1994. Perceived Service Quality and User Satisfaction with the Information Services Function*. Decision Sciences 25, 737-766.

Kettinger, W.J., Lee, C.C., 1995. Exploring a "gap" model of information services quality. Information Resources Management Journal (IRMJ) 8, 5-17.

Kettinger, W.J., Lee, C.C., 1999. Replication of Measures in Information Systems Research: The Case of IS SERVQUAL*. Decision Sciences 30, 893-899.

Kettinger, W.J., Lee, C.C., 2005. Zones of tolerance: alternative scales for measuring information systems service quality. MIS Quarterly 29, 607-623.

Kim, G., Shin, B., Kwon, O., 2012. Investigating the Value of Sociomaterialism in Conceptualizing IT Capability of a Firm. Journal of Management Information Systems 29, 327362. 
Lai, F., Griffin, M., Babin, B.J., 2009. How quality, value, image, and satisfaction create loyalty at a Chinese telecom. Journal of Business Research 62, 980-986.

Law, K.S., Wong, C.-S., Mobley, W.M., 1998. Toward a taxonomy of multidimensional constructs. Academy of Management Review 23, 741-755.

Lee, D.-J., Sirgy, M.J., Larsen, V., Wright, N.D., 2002. Developing a subjective measure of consumer well-being. Journal of Macromarketing 22, 158-169.

Lepmets, M., Cater-Steel, A., Gacenga, F., Ras, E., 2012. Extending the IT service quality measurement framework through a systematic literature review. Journal of Service Science Research 4, 7-47.

Limayem, M., Hirt, S.G., Cheung, C.M., 2007. How habit limits the predictive power of intention: the case of information systems continuance. MIS Quarterly, 705-737.

Lincoln, Y.S., 1985. Naturalistic inquiry. Sage.

London, T., 2009. Making better investments at the base of the pyramid. Harvard Business Review 87, 106-113.

Lucas Jr, H.C., Agarwal, R., El Sawy, O.A., Weber, B., 2013. Impactful Research on Transformational Information Technology: An Opportunity to Inform New Audiences. Management Information Systems Quarterly 37, 371-382.

Lusch, R.F., Vargo, S.L., 2006. The service-dominant logic of marketing: dialog, debate, and directions. ME Sharpe Inc.

Lusch, R.F., Vargo, S.L., O’Brien, M., 2007. Competing through service: Insights from service-dominant logic. Journal of retailing 83, 5-18.

Lusch, R.F., Vargo, S.L., Tanniru, M., 2010 Service, value networks and learning. Journal of the Academy of Marketing Science 38, 19-31.

Machuca, J.A.D., González-Zamora, M.d.M., Aguilar-Escobar, V.G., 2007. Service Operations Management research. Journal of Operations Management 25, 585-603.

MacKenzie, S.B., Podsakoff, P.M., Jarvis, C.B., 2005. The problem of measurement model misspecification in behavioral and organizational research and some recommended solutions. Journal of Applied Psychology 90, 710-729.

Maglio, P.P., Kwan, S.K., Spohrer, J., 2015. Commentary-Toward a research agenda for human-centered service system innovation. Service Science 7, 1-10.

Maglio, P.P., Spohrer, J., 2008. Fundamentals of service science. Journal of the Academy of Marketing Science 36, 18-20.

Maglio, P.P., Spohrer, J., 2013. A service science perspective on business model innovation. Industrial Marketing Management.

Maglio, P.P., Vargo, S.L., Caswell, N., Spohrer, J., 2009. The service system is the basic abstraction of service science. Information Systems and e-business Management 7, 395-406.

Moore, G.C., Benbasat, I., 1991. Development of an instrument to measure the perceptions of adopting an information technology innovation. Information Systems Research 2, 192-222.

Motamarri, S., Akter, S., Ray, P., Tseng, C.-L., 2014. Distinguishing 'mHealth' from other healthcare services in a developing country: a study from the service quality perspective. Commun. Assoc. Inf. Syst 34, 669-692.

Nelson, R.R., Todd, P.A., Wixom, B.H., 2005. Antecedents of information and system quality: an empirical examination within the context of data warehousing. Journal of Management Information Systems 21, 199-235. 
Ng, I., Maull, R., Smith, L., 2011. Embedding the new Discipline of Service Science, H. Demirkan et al.(Eds.), The Science of Service Systems, Service Science: Research and Innovations (SSRI) in the Service Economy. Springer.

Öhman, M., Finne, M., Holmström, J., 2015. Measuring service outcomes for adaptive preventive maintenance. International Journal of Production Economics 170, Part B, 457-467.

Oliver, R.L., 1999. Whence consumer loyalty? the Journal of Marketing, 33-44.

Oliver, R.L., Rust, R.T., Varki, S., 1997. Customer delight: foundations, findings, and managerial insight. Journal of Retailing 73, 311-336.

Orlikowski, W.J., 2007. Sociomaterial practices: Exploring technology at work. Organization studies 28, 1435-1448.

Orlikowski, W.J., Iacono, C.S., 2001. Research commentary: Desperately seeking the" it" in it research - a call to theorizing the it artifact. Information Systems Research 12, 121-134.

Orlikowski, W.J., Scott, S.V., 2008. 10 Sociomateriality: Challenging the Separation of Technology, Work and Organization. The academy of management annals 2, 433-474.

Ostrom, A.L., Bitner, M.J., Brown, S.W., Burkhard, K.A., Goul, M., Smith-Daniels, V., Demirkan, H., Rabinovich, E., 2010. Moving forward and making a difference: research priorities for the science of service. Journal of Service Research 13, 4-36.

Ostrom, A.L., Parasuraman, A., Bowen, D.E., Patrício, L., Voss, C.A., 2015a. Service Research Priorities in a Rapidly Changing Context. Journal of Service Research 18, 127-159.

Ostrom, A.L., Parasuraman, A., Bowen, D.E., Patrício, L., Voss, C.A., Lemon, K., 2015 b. Service Research Priorities in a Rapidly Changing Context. Journal of Service Research 18, 127159.

Parasuraman, A., 1990. Delivering quality service: Balancing customer perceptions and expectations. New York: Free Press; London: Collier Macmillan.

Parasuraman, A., Grewal, D., 2000. The impact of technology on the quality-value-loyalty chain: a research agenda. Journal of the academy of marketing science 28, 168-174.

Parasuraman, A., Zeithaml, V., Berry, L., 1985. A conceptual model of service quality and its implications for future research. the Journal of Marketing, 41-50.

Parasuraman, A., Zeithaml, V., Berry, L., 2005. ES-QUAL a multiple-item scale for assessing electronic service quality. Journal of Service Research 7, 213-233.

Parasuraman, A., Zeithaml, V.A., Berry, L.L., 1988. Servqual. Journal of Retailing 64, 12-40.

Patterson, P.G., Spreng, R.A., 1997. Modelling the relationship between perceived value, satisfaction and repurchase intentions in a business-to-business, services context: an empirical examination. International Journal of Service Industry Management 8, 414-434.

Payne, A.F., Storbacka, K., Frow, P., 2008. Managing the co-creation of value. Journal of the Academy of Marketing Science 36, 83-96.

Petter, S., McLean, E.R., 2009. A meta-analytic assessment of the DeLone and McLean IS success model: An examination of IS success at the individual level. Information \& Management 46, 159-166.

Petter, S., Straub, D., Rai, A., 2007. Specifying formative constructs in information systems research. MIS Quarterly 31, 623-656.

Pitt, L.F., Buliding, A., Watson, R.T., 1997. Information Systems Service Quaiity: Concerns for a Compiete Canvas. MIS Quarterly, 209.

Pitt, L.F., Watson, R.T., Kavan, C.B., 1995. Service quality: a measure of information systems effectiveness. MIS Quarterly, 173-187. 
Podsakoff, P.M., MacKenzie, S.B., Lee, J.-Y., Podsakoff, N.P., 2003. Common method biases in behavioral research: a critical review of the literature and recommended remedies. Journal of applied psychology 88, 879 .

Podsakoff, P.M., Organ, D.W., 1986. Self-reports in organizational research: Problems and prospects. Journal of management 12, 531-544.

Poiesz, T.B., von Grumbkow, J., 1988. Economic well-being, job satisfaction, income evaluation and consumer satisfaction: An integrative attempt, Handbook of economic psychology. Springer, pp. 570-593.

Polites, G.L., Roberts, N., Thatcher, J., 2011. Conceptualizing models using multidimensional constructs: a review and guidelines for their use. European Journal of Information Systems 21, 22-48.

Porter, M.E., Teisberg, E.O., 2004. Redefining competition in health care. Harvard Business Review, 64-77.

Prahalad, C.K., 2009. The Fortune at the Bottom of the Pyramid, Revised and Updated 5th Anniversary Edition: Eradicating Poverty Through Profits. FT Press.

Prahalad, C.K., Hammond, A., 2002. Serving the world's poor, profitably. Harvard Business Review 80, 48-59.

Reeves, C.A., Bednar, D.A., 1994. Defining Quality: Alternatives and Implications. Academy of Management Review 19, 419-445.

Ringle, C., Sarstedt, M., Straub, D., 2012. A critical look at the use of PLS-SEM in MIS quarterly. MIS Quarterly (MISQ) 36.

Ringle, C., Wende, S., Becker, J., 2015. Smart PLS 3. Boenningstedt: SmartPLS GmbH.

Rosenbaum, M.S., 2008. Return on Community for Consumers and Service Establishments. Journal of Service Research 11, 179-196.

Ruiz, D.M., Gremler, D.D., Washburn, J.H., Carrión, G.C., 2008. Service value revisited: specifying a higher-order, formative measure. Journal of Business Research 61, 1278-1291.

Rust, R.T., Huang, M.-H., 2014. The service revolution and the transformation of marketing science. Marketing Science 33, 206-221.

Säilä, T., Mattila, E., Kaila, M., Aalto, P., Kaunonen, M., 2008. Measuring patient assessments of the quality of outpatient care: a systematic review. Journal of evaluation in clinical practice $14,148-154$.

Schneider, B., 2004. Service quality: Research perspectives. Sage.

Sheth, J.N., Newman, B.I., Gross, B.L., 1991. Consumption values and market choices: Theory and applications. South-Western Pub.

Sirgy, M.J., Cornwell, T., 2001. Further validation of the Sirgy et al.'s measure of community quality of life. Social Indicators Research 56, 125-143.

Sirgy, M.J., Lee, D.-J., Bae, J., 2006. Developing a measure of Internet well-being: Nomological (predictive) validation. Social Indicators Research 78, 205-249.

Sobel, M.E., 1982. Asymptotic confidence intervals for indirect effects in structural equation models. Sociological methodology 13, 290-312.

Sousa, R., Voss, C.A., 2006. Service quality in multichannel services employing virtual channels. Journal of Service Research 8, 356-371.

Spohrer, J., Maglio, P.P., Bailey, J., Gruhl, D., 2007. Steps toward a science of service systems. Computer 40, 71-77.

Sprague, L.G., 2007. Evolution of the field of operations management. Journal of Operations Management 25, 219-238. 
Spreng, R.A., MacKenzie, S.B., Olshavsky, R.W., 1996. A reexamination of the determinants of consumer satisfaction. the Journal of Marketing, 15-32.

Srinivasan, A., Kurey, B., 2014. Creating a Culture of Quality. Harvard Business Review 92, 23-25.

Straub, D., Boudreau, M.-C., Gefen, D., 2004. Validation guidelines for IS positivist research. Communications of the Association for Information Systems 13, 380-427.

Straub, D.W., 2009. Editor's comments: why top journals accept your paper. MIS Quarterly 33, III-X.

Svensson, G., Grönroos, C., 2008. Service logic revisited: who creates value? And who cocreates? European business review 20, 298-314.

Sweeney, J.C., Soutar, G.N., 2001. Consumer perceived value: the development of a multiple item scale. Journal of Retailing 77, 203-220.

Taylor, S.A., Baker, T.L., 1994. An assessment of the relationship between service quality and customer satisfaction in the formation of consumers' purchase intentions. Journal of Retailing 70, 163-178.

Tenenhaus, M., Vinzi, V.E., Chatelin, Y.-M., Lauro, C., 2005. PLS path modeling. Computational statistics \& data analysis 48, 159-205.

Vargo, S.L., Lusch, R.F., 2004. Evolving to a new dominant logic for marketing. Journal of marketing 68, 1-17.

Vargo, S.L., Lusch, R.F., 2008. Service-dominant logic: continuing the evolution. Journal of the Academy of Marketing Science 36, 1-10.

Vargo, S.L., Lusch, R.F., 2011. It's all B2B... and beyond: Toward a systems perspective of the market. Industrial Marketing Management 40, 181-187.

Vargo, S.L., Lusch, R.F., 2016. Institutions and axioms: an extension and update of servicedominant logic. Journal of the Academy of Marketing Science 44, 5-23.

Vargo, S.L., Maglio, P.P., Akaka, M.A., 2008. On value and value co-creation: A service systems and service logic perspective. European management journal 26, 145-152.

Varshney, U., 2005. Pervasive healthcare: applications, challenges and wireless solutions. Communications of the Association for Information Systems 16, 3.

Wakefield, K.L., Barnes, J.H., 1997. Retailing hedonic consumption: a model of sales promotion of a leisure service. Journal of Retailing 72, 409-427.

Wetzels, M., Odekerken-Schroder, G., Van Oppen, C., 2009. Using PLS path modeling for assessing hierarchical construct models: guidelines and empirical illustration. MIS Quarterly 33, 177.

Whetten, D.A., 1989. What constitutes a theoretical contribution? Academy of Management Review 14, 490-495.

Widaman, K.F., 1985. Hierarchically nested covariance structure models for multitraitmultimethod data. Applied Psychological Measurement 9, 1-26.

Wixom, B.H., Todd, P.A., 2005. A theoretical integration of user satisfaction and technology acceptance. Information Systems Research 16, 85-102.

Woodside, A.G., Frey, L.L., Daly, R.T., 1989. Linking service quality, customer satisfaction, and behavioral intention. Journal of Health Care Marketing 9, 5.

Wu, L.-C., Wu, L.-H., 2015. Improving the global supply chain through service engineering: A services science, management, and engineering-based framework. Asia Pacific Management Review 20, 24-31. 
Xu, J.D., Benbasat, I., Cenfetelli, R.T., 2013. Integrating service quality with system and information quality: An empirical test in the e-service context. Management Information Systems Quarterly 37, 777-794.

Yee, R.W.Y., Yeung, A.C.L., Edwin Cheng, T.C., 2010. An empirical study of employee loyalty, service quality and firm performance in the service industry. International Journal of Production Economics 124, 109-120.

Yuan, L.L., 2001. Quality of life case studies for university teaching in sustainable development. International journal of sustainability in higher education 2, 127-138.

Zeithaml, V.A., 1988. Consumer perceptions of price, quality, and value: a means-end model and synthesis of evidence. the Journal of Marketing, 2-22.

Zeithaml, V.A., Berry, L.L., Parasuraman, A., 1996. The behavioral consequences of service quality. the Journal of Marketing, 31-46. 